\title{
HISTORY AS FUTURE-TIME, PREDICTION, AND HISTORICAL NARRATIVE IN THE ZUO ZHUAN
}

\author{
Piotr Gibas*
}

\begin{abstract}
This article demonstrates that historical narrative in the Zuo zhuan is founded on the concept of "timeliness," that is, on the understanding of time as being endowed with moral qualities. The choice between a “timely" (shi 時) or "untimely" (bu shi 不時) course of action determines the success or failure of the person involved in it. The origins of the ideas of time that shape the historical narrative of Zuo zhuan can be traced to mantic literature of the same period, such as almanacs.

Early Chinese writers of history-like diviners-strove to explain the past in order to predict the future. Seen in this light, "knowing history" implies understanding and mastering the mechanisms that drive it; and looking into the past is tantamount to "knowing" the future.
\end{abstract}

\section{Introduction}

In this study, I analyze the role of timeliness in the Zuo zhuan 左傳 "Zuo Tradition" as a means of demonstrating the relationship between prognosticating and history writing. Preoccupation with the past is one of the most noticeable features of Chinese thought of all ages. In the earliest inscriptions on oracle bones and bronze vessels, followed by myths, poetry, and historiographical works, the early Chinese thinkers were assiduous in their attempts to explain the past and to define the meaning and functions of history. This ceaseless quest eventually found its culmination in the production of historical narrative, which served not so much as a means of presenting the past, as one of "finding" and "recovering" the past for the sake of the "here and now," and of thereby ensuring a safe and auspicious future. I argue that historiography is a form of omenology, where historical precedence is recorded, and then interpreted and evaluated according to the criterion of timeliness for the purpose of predicting the future; in effect, history writing is tantamount to omen reading.

*Piotr Gibas, 齊百思, College of Charleston; gibaspp@cofc.edu.

(C) The Society for the Study of Early China and Cambridge University Press 2018 
Using examples from Chunqiu 春秋 and Zuo zhuan, I will explore the manner in which early Chinese historical writings are founded on the concept of "timeliness," that is, on the understanding of time as being endowed with moral qualities. "Timely" (shi 時) actions and events carry a positive moral charge; they are felicitous, right, safe, and harmonious within the general progress and scheme of history. Whatever is untimely (bu shi 不時), on the other hand, is wrong, dangerous, and unpropitious, and it inevitably leads to failure. Central to this moral understanding of time is the concept of ming 明—“sagely illumination," or the ability to discern between good and bad, right and wrong, deserving and undeserving, that is, between what is timely and untimely. Historiography, then, represents history as a means of rewarding the timely and punishing the untimely.

In the Zuo zhuan, which is the earliest received Chinese historical narrative ${ }^{1}$ history is narrated as prognosticated future and told through the life-stories of its actors-"historical figures" - the individuals who left a mark in the past and who serve as examples for the future. I will propose a reading of the sample story of Duke Wen of Jin in order to demonstrate that the choice between a "timely" or "untimely" course of action determines the success or failure of the historical figure involved in it.

My work in this area owes much to David Schaberg and Wai-yee Li, whose studies on the "readability" of early Chinese written history, and the practice of decoding the patterns and signs typically conveyed therein, show that the pursuit of the past is not for the purpose of mere recording, but, rather, is motivated by a conscious desire to find answers applicable to the present. ${ }^{2}$ My study also pays a special homage to Mark Kalinowski's work on the "predictive discourses" in the Zuo zhuan; as he argues, there exists a coherent "predictive style" in the narrative, which the compilers use to expose their views about history and its actors. Most notably, Kalinowski points out that sagehood is a necessary condition in exercising the predictive faculties of the human spirit. ${ }^{3}$

1. According to Zhongguo wenxue dacidian 中國文學大詞典, the Zuo zhuan is “the Nation's earliest, detailed, vividly narrated chronological history, and, at the same time, a historical narrative with high literary quality” (我國古代最早而又詳細完備、敘 事生動的編年史, 同時也是文學成就很高的歷史散文著作): Ma Liangchun 馬良春 and Li Futian 李福田, eds., Zhongguo wenxue dacidian 中國文學大詞典 (Tianjin: Tianjin ren$\min , 1991), 1413$.

2. David Schaberg, A Patterned Past: Form and Thought in Early Chinese Historiography (Cambridge: Harvard East Asian Monographs, 2002); Wai-yee Li, The Readability of the Past in Early Chinese Historiography (Cambridge: Harvard University Asia Center, 2007).

3. Marc Kalinowski, "La rhétorique oraculaire dans les chroniques anciennes de la Chine: Une etude des discours prédictifs dans le Zuozhuan," Extrême-Orient, Extrême-ccident (Divination et rationalité en Chine ancienne) 21 (1999), 37-65. 
Building on these observations and by teasing out the workings of prediction and prognostication in the narrative, I demonstrate how history writing aspired to the control and manipulation of historical time; by creating a narrative of the past and consolidating its multiple links to the future, the early Chinese writers of history-like diviners-strove to explain it and, thus, to conquer it. Seen in this light, "knowing history" implies understanding and mastering the mechanisms that drive it; and, looking into the past is tantamount to "knowing" the future. "Historical figures" in the Zuo zhuan who possess "sagely illumination" are presented as being aware of their own historicity, and they consciously negotiate and create their historical profiles to represent them in the future. Ultimately, then, I will examine how historical narrative shapes the profile of a perfect "sage ruler," who controls the present, because he knows the past and is able to foresee the future. Early Chinese historical narrative shows that people-historical figures, heroes, sages-just like other occurrences and phenomena in nature, may be timely or untimely; this is not only a question of whether or not they act in the right time, but their very appearance and presence in history also is the matter of timeliness.

I trace the origins of the ideas of time that shape the historical narrative of Zuo zhuan to contemporary hemerological tradition, such as the rishu 日書 "daybooks" or "almanacs" and the yue ling 月令 "monthly ordinances," which enable humans to manipulate time and "create" history. The sagely figure, whose moral standing and political capacities are conditioned by temporal issues, emerges from the mantic tradition and is further developed in the Zuo zhuan. It is the occult practices and cults that constitute the backbone of later concepts of morality and spur the idea of the omenological and didactic functions of history writing. Similar to a daybook, the Zuo zhuan is also a manual-it advises choosing the right and auspicious course of action.

In what follows, I will first discuss the ritual nature of Chunqiu annals and their relationship with the Zuo Tradition; the original functions of early historiography, and the Annals in particular, are key in understanding the ideas about history and history writing.

\section{Creation of a Historical Narrative-Temporal Structure of the Zuo Zhuan}

In the fourteenth year of Duke Ai 衰公 (481 B.C.E.), an extraordinary and highly significant event took place in the state of Lu 魯. During the annual winter hunt, the charioteers captured a unicorn lin 麟. According to the sources, the rare animal was injured, then transported to the capital, and eventually killed. Confucius, who had a chance to examine the 
finding, was deeply shaken by it. He deemed the unicorn's appearance "untimely" - bu shi-and lamented its fate. Later traditions claim that it was this event that prompted the Sage to compile the Chunqiu annals; 4 there are others who believe the contrary: it was at this point that he stopped making the records. ${ }^{5}$ Regardless of which is the truth, it is certain that this unique occurrence became the turning point in the Chinese perception and writing of history. The finding of the unicorn could not be left without an explanation. What happened in the past that caused it to come? What was going to happen thereafter?

In her discussion of the Zuo zhuan account of the event, Wai-yee Li points out that "the capture of the $\operatorname{lin}$ is about the failure of recognition." 6 The people who catch the animal misidentify and, consequently, mishandle it. It takes a sage such as Confucius to correct their mistake and call the thing by its correct name. This can be deduced, in part, from the terse language of the passage:

\section{仲尼觀之曰麟也。}

\section{Zhongni examined it and said, "It is a lin."}

The hunters were not sure what they had caught; the finding was not just a rare specimen, but also something altogether unknown to them. They deemed it "anomalous" yi 異 and "inauspicious" bu xiang 不祥, and therefore potentially dangerous. What the Sage performs over the injured lin is an act of identification, and only after he demystifies it and calls it by its proper name do they accept it as the kill of the hunt.7

However, the role of the Sage here is not limited to the mere classifying of the finding in terms of species and type. The verb guan 觀 "to inspect" used in the text suggests his personal involvement with the object of examination: getting an idea of what it is, recognizing it, and understanding it. Confucius not only examines the animal's physicality, but he sees its nature and understands what its coming implies. ${ }^{8}$

4. This is the point of view of the Jin 晉 scholar and Zuo zhuan interpreter Du Yu 杜預 (222-284 C.E.) and his followers: James Legge, The Ch'un Ts'ew with the Tso Chuen, The Chinese Classics 5 (Taipei: SMC Publishing, 1994), 834.

5. The Gongyang zhuan 公羊傳 tradition.

6. Wai-yee Li, The Readability of the Past, 416.

7. There probably existed registers of animals that were eligible for hunting and the capture of which was reported in the ancestral temple after the hunt. Hunting expeditions were ritual events and their outcome was ominous; killing of a "wrong" animal could be inauspicious and bring undesirable consequences. Here, it seems that the hunters deemed the unicorn such an animal.

8. According to Wang Li, 觀 guan means "to look intently and with an aim/purpose" (有目的地看): Wang Li guhanyu zidian 王力古漢語字典 (Beijing: Zhonghua, 200o), 
The Spring and Autumn Annals Chunqiu and Zuo zhuan are the two earliest extant Chinese historiographical works. According to tradition, Chunqiu - a chronicle of events that took place in Lu between 722 and 481 B.C.E. - was composed by Confucius, whereas the Zuo zhuan was believed to have been written as a commentary on the Chunqiu by Confucius' disciple Zuo Qiuming 左丘明, a state shi 史一“historiographer" in Lu. ${ }^{9}$ Unlike Chunqiu, which is a register of unelaborated events, Zuo zhuan is a collection of narratives purporting to explain exactly what happened; that is, as the positivist historian Leopold von Ranke famously put, "wie es eigentlich gewesen" (how it actually was). ${ }^{10}$ Moreover, the Zuo zhuan in many instances refers directly to particular entries in the Chunqiu and explains why the record was made, thus exposing the ritualistic nature of the work.

The references to Chunqiu in the Zuo zhuan show that the former was not a mere chronicle of events, but rather a register of carefully selected material. Based on the analysis of its contents, Li Zongtong 李 宗侗 argues that Chunqiu is a strictly ritual text. ${ }^{11}$ As he points out, all

and according to Shuowen jiezi 說文解字 (Jinan: Qi Lu Shushe, 1994), it means "to inspect/examine/scrutinize" (諦視也). One of the basic dictionary definitions for guan is “to have the understanding/knowledge/recognition of a matter" (對事物的認識), hence the nominal form "an opinion" or "a point of view" — a personal "understanding" of a matter developed as a result of a close insight and investigation. Guan in this sense involves a judgment and it can be translated as "to regard something as." According to Wang $\mathrm{Li}$, "in the meaning of guan there lies a heavy emphasis on the subjective purposefulness of the agent" (觀的意義重在施事者的主觀目的性), and a passage in the Zuo zhuan (Duke Zhuang, 23rd year) criticizes the ruler for breaking the rules of propriety: "What kind of lesson is your posterity going to derive from this?" (後嗣何觀) (Hanyu da cidian 漢語大詞典, Shanghai: ci shu, 1993, interprets guan in this phrase as jie jian 借鑒 "to derive a lesson."). Guan implies interpreting the object and learning from it; it suggests that the object of scrutiny purports something.

9. Zuo Qiuming's relationship to Confucius was first suggested by $\mathrm{Du} \mathrm{Yu}$ in his work Chunqiu Zuoshi jing zhuan ji jie $x u$ 春秋左氏經傳集解序.

10. Georg G. Iggers and James M. Powell, eds., Leopold von Ranke and the Shaping of the Historical Discipline (Syracuse: Syracuse University Press, 1990), xiv-xv; Ranke's principle became the guideline for modern historians striving to present the facts of history without their own views. In the context of early Chinese historiography, Ranke's definition of historical narrative helps highlight the difference between Chunqiu and the Zuo zhuan, where the former records the events, and the latter describes them; therefore, unlike Chunqiu, the Zuo zhuan is a text that reflects the authors' cognitive interest in the past and their historical consciousness. In other words, the text of Chunqiu is insufficient as a description of the past; it is the Zuo zhuan that provides the historical background for the facts recorded in the Annals, and thus, for the first time in Chinese tradition, attempts to answer the question of "what actually happened."

11. Li divides the events recorded in Chunqiu into thirty thematic groups and points out that all of them have a religious character and are related to the ritual, e.g. records of covenants, which involved a particular ceremony, as well as hunts, funerals, earth 
the undertakings and events mentioned in it were announced to the ancestors during the divination and sacrificial ceremonies. Li concludes that the records were originally made exclusively for the use in the temple, and that they acquired their more universal and didactic function only later; therefore, not all the events were recorded, but only those that were relevant from the ritual point of view, i.e. that were required to be announced to the ancestors. According to A. M. Karapetiantz, the Chunqiu records were made on bamboo tablets not as chronicle entries for posterity, but as reports to the ancestors; the act of inscribing the tablets was in itself part of the ritual. The tablets were presented as offerings on the altar, and the written language served as the medium for transmitting the information into the afterworld. ${ }^{12}$

In his study of the structure of Chunqiu, Karapetiantz focuses on the system employed to date the entries. As he observes, the date of the event could be omitted or changed in the records because of ritual reasons, and events were dated with different degrees of accuracy (season, month, and/or day) depending on their ritual significance. ${ }^{13}$ This fact

and construction works, and other. Li Zongtong 李宗侗, “Shiguan zhidu—fu lun dui chuantong zhi zunzhong” 史官制度 - 附論對傳統之尊重, Taiwan daxue wenshizhe xuebao 14 (1965), 14 .

12. Karapetiantz compares Chunqiu to the inscriptions on oracle bones; he argues that the bones were offered on the altar along with ritual sacrifices with the purpose of transmitting information to the ancestors: Артемий М. Карапетьянц, «Чунь Цю» и древнекитайский «историографический» ритуал, Этика и ритуал в традиционном Kumae (Artemii M. Karapetiantz, "'Chunqiu and the Ancient Chinese 'Historiographical' Ritual," Ethics and Ritual in Traditional China) (Moscow: Nauka, 1988), 86. See also Shirakawa on using writing as a tool for communicating with the spirits and on the apotropaic function of the text. Shizuka Shirakawa 白川靜, Kanji no sekai 漢字の世界, 2 vols. (Tokyo: Heibonsha, 1976).

13. Karapetiantz divides events with ritual significance recorded in Chunqiu into different categories (sacrifice, deaths, murders, funerals), and observes that, depending on category, some kinds of ritual events are either always or never dated using 干支 ganzhi cyclical signs; for example, records of sacrifice, fires, earthquakes, falling meteors, sun eclipses, announcements of deaths of rulers from principal states and wives of the dukes and officers of $\mathrm{Lu}$, announcements of funerals of Lu dukes and their wives, and of the arrival of a funerary procession in $\mathrm{Lu}$, are always dated using ganzhi. Another type of activity that is often but not always dated using cyclical signs is the covenant (in my opinion covenant is a ritual event, but Karapetiantz does not classify it as such). Karapetiantz analyzes all records of 盟 meng and observes that, within this group, if the record names the initiator of the covenant it is always dated with ganzhi; if, however, the initiator of the covenant is not named, then only the month and season are recorded; arrivals at covenants are usually dated only to the season. The most frequent reports found in Chin qiu are of deaths and funerals; in them, we see the correlation between not only the dating and the contents, but also the place where the event takes place. Karapetiantz also observes that each state applied its own method of recording such events. From these observations, Karapetiantz concludes that the 
reveals the importance of the ideas about time in the process of the creation of the text-it shows that the date does not have a merely informative and documentary function, but instead it constitutes a part of the event, or even - in cases of a complete omission of the entry-an event in its own right. ${ }^{14}$ As Zbigniew Słupski puts it, "time was that element which linked people with the higher order, with the order of Nature, with the order of Heaven."15

As the following discussion will show, the seasons were "assigned" by Heaven and expressed Heaven's will; therefore, any activity undertaken by people on earth had to be coordinated with them. The ritual text of Chunqiu can be considered a reflection and a sanction of that natural order; the text was composed following the course of time and, as such, the records were also an element of time-its expression and representation.

In more than 200 direct references to Chunqiu, the Zuo zhuan explains why certain events were recorded-formulae shu 書—or why they were not recorded-formulae $b u$ shu 不書. ${ }^{16}$ For a large part, these records are related to time: they were made in order to advise whether events were "timely" —formulae shi 時—or "untimely"—formulae bu shi. ${ }^{17}$

method of dating depends on the kind of report, and that recording was regulated by strict ritual rules. Karapetiantz, Chunqiu, 141.

14. The structure of each Chunqiu entry is very regular: the reign year is followed by the current season; after that, there is either a record of an event or the indication of the month. Each season has three months and, theoretically, all three can be indicated in the text; but in practice, there is not a single instance of the season where events are recorded for all three months; moreover, there are thirty-six cases of seasons with no records of any events and no indications of the first month in the season. When the month is indicated, there may be a record of events that took place in that month; there can also be indications of the cyclical days, with or without the records of the corresponding events. Characteristically, there is no instance in which a new season is not announced, and from this James Legge concluded that the coming of the new season was important in its own right and as such had to be recorded. In such cases, the record testifies that Nature is conforming to its proper course; the omission of the record of a change in season would indicate a deviance from that course and a cosmic cataclysm: Legge, ed., The Ch'un Ts'ew with the Tso Chuen, 21.

15. Zbigniew Słupski, "The Literary Structure of the Chunqiu and the Zuo zhuan," Archív Orientální 69 (2001), 56.

16. Whenever referring to the "rules of recording" (shufa 書法) in the Chunqiu, the Zuo zhuan uses the same set of technical terms and expressions; I consider them "formulae," because they are fixed groups of words used only in particular context.

17. As I have demonstrated elsewhere, most of the references regarding timeliness concern construction works. For example, there are nine reports in Chunqiu on walling cities—cheng 城, and each of them is commented upon in the Zuo zhuan, according to which in six instances the works were deemed timely, and in two untimely; in only one instance is there no reference to time. See Piotr Gibas, “Летопись Чуньцю и ритуальное значение времени в период Чуньцю” “"Chunqiu Annals and Ritual Significance of Time 
As the Zuo zhuan comments indicate, these formulae were morally charged-a "timely" action was right, and an "untimely" one wrong. ${ }^{18}$ Thus, according to the Zuo zhuan, one of the purposes of the Chunqiu reports was to evaluate the events and, by extension, to praise or to blame the people responsible for them.

The life of the people and the administration of the state were subordinated to the laws of Nature. Heaven established seasons, which could not be transgressed, and any kind of activity had to be completed at the right time. The calendar and the state agendas were determined by reading the signs received from Heaven. This was accomplished under the personal supervision of the ruler, who was Heaven's representative on earth and the initiator of the changes in the vegetation. ${ }^{19}$ As Yang Bojun explains, the feudal lords announced the beginning of each month in the temple during sacrificial ceremonies, when a ritual record of it was also made. ${ }^{20}$ No action in the state could be taken without the ceremonial announcement of the new season; therefore, it is correct to say that the Annals were made because of or due to time.

The untimeliness of an action was an event important enough to be written down and reported to the ancestors. Karapetiantz points out that all the seasonal sacrifices recorded in Chunqiu are anomalous..$^{21}$ The Chunqiu should be considered a ritual text not because it records ritual activities-a regular sacrifice ceremony was not an event that needed to be recorded. It was not the event itself that was important, but its ritual relevance, such as the relationship with time. The records were aimed at exposing those who obeyed or disobeyed the ritual — the order of timeliness. The formulae shu and $b u$ shu were ritual commands that the writers of the text had to follow. Time acquires a ritual significance and becomes a form of sacrum; a disturbance of its order could not go unnoticed in a ritual text such as Chunqiu.

in the Spring and Autumn Period"), Russian Academy of Sciences Proceedings G.7-8 (2001), 38-45.

18. One good example is the passage in Zuo zhuan Duke Xiang thirteenth year, where the timely walling of Fang is deemed to be in accordance with the rules of the ritual $l i$ 禮: Yang Bojun 楊伯峻, Chunqiu Zuo zhuan zhu 春秋左傳注 (Beijing: Zhonghua, 1990), 1002.

19. The crucial role of the ruler in the ceremonies and practices involved in interpreting celestial signs and fixing the calendar can be seen in Zuo zhuan Duke Xi fifth year.

20. Yang Bojun, Chunqiu Zuo zhuan, 52-54.

21. The narrative in Duke Huan fifth year explains that if there is an error in the sequence of seasonal sacrifices, i.e. if the ceremony takes place "out of the right season, it must be recorded [in the Annals]" (過則書): Yang Bojun, Chunqiu Zuo zhuan, 107. Otherwise, sacrificial ceremonies were not recorded: Karapetiantz, Chunqiu, 128. 
The officers shi 史, in Sinological literature customarily denominated "historiographers," who were the actual authors of both the Chunqiu and the Zuo zhuan, paid a lot of attention not only to how things happened, but, more importantly, why and when, and they regarded these two aspects as tightly interconnected.

The accounts that comprise the Zuo zhuan were originally composed by multiple authors as separate texts of their own, independently from the Chunqiu. Only later were they rearranged and put together into one "book," which was further tailored in order to fit the Annals and serve as a commentary on them. This can be seen from the structure of the received text. ${ }^{22}$ Henri Maspero argues that the received Zuo zhuan text was made up of two different works: an actual commentary on the Annals, mainly concerned with ritual and ethics—such as the historiographical references shu and $b u$ shu I discussed above-and a historical narrative that was written independently from Chunqiu and related to another contemporary collection of historical narratives, the Guo yu 國語, also attributed to Zuo Qiuming; similarly to the latter, the Zuo zhuan narrative is also focused on the state of Jin 晉 instead of $\mathrm{Lu}$, which further supports Maspero's thesis. ${ }^{23}$

The most notable difference between the Chunqiu and Zuo zhuan is that the former presents the events without description; this is because, unlike the Zuo zhuan, Chunqiu was originally a ritual text. Li Ling classifies the historiographical works in the Warring States period (453-221 в.C.E.) into two large groups: the "genealogies" or "historical records" pudie 譜牒 / shiji 史記, and “narratives" shiyu 事語. In his view, the latter-among them the Zuo zhuan-originate from oral tradition. They narrate the past events in retrospect using literary language, but they

22. Zuo Qiuming's authorship and the assumption that the Zuo zhuan was written as a commentary to the Chunqiu were first proposed by Sima Qian 司馬遷 in the Shi ji 史記 (Beijing: Zhonghua, 1959), and later supported by Du Yu. Yang Bojun questions the historicity of Zuo Qiuming and dismisses the traditional theory of one author altogether; he argues that the actual "author" was a person who collected and edited writings composed by different people at different times, hence the homogeneous style: Yang Bojun, Chunqiu Zuo zhuan, 33-34. Han shu 漢書 has an account of Liu Xin 劉歆 (46 B.C.E.-23 C.E.), who discovered ancient versions of both Chunqiu and Zuo zhuan in secret imperial archives and arranged them together: Ban Gu 班固, Han shu (Beijing: Zhonghua, 1962), 1967. The New Text school in Han rejected the idea of the Zuo zhuan being a Chunqiu commentary pointing at the discrepancies between the two texts. Liu Fenglu 劉逢祿 (1776-1829) believed that the Zuo zhuan was Liu Xiang's forgery based on the Guo yu 國語 tailored to fit Chunqiu; this idea was supported by Otto Franke in his Studien zur Geschichte des konfuzianischen Dogmas und der chinesischen Staatsreligion (Hamburg: L. Friedrichsen, 1920), 6of.

23. Henri Maspero, "La composition et la date du Tso-chuan," Mélanges chinois et bouddiques I (1931-32), 137-215. 
retain their colloquial style and story-telling structure. Li Ling argues that the authors made a conscious effort to make the narratives look colloquial, which resulted in creating "literary history books" wei wenxue chuangzao de shi shu 為文學創造的史書. They emerged independently from the chronicles, but may have been later "combined" with texts like Chunqiu—belonging to the "historical records" category—in order to serve as commentaries on them. ${ }^{24}$

Thus, as we see the text nowadays, Chunqiu presents the events as they occur-in a linear chronological sequence, and the "commentary" - the Zuo zhuan - explains them in retrospect, not merely narrating what exactly happened, but often providing the whole background of an event, reaching far into the past, as well as anticipating or suggesting what is going to happen in the future. Kalinowski labels this style of narrative "predictive discourses" and considers them a particular literary genre, something halfway between the discursive mode of the arguments in the advices and the oracular mode of the divinatory consultations. As he observes, apart from their strictly predictive functions, predictions also play an active role in the narrative, such a passing a judgment about a person, legitimizing an action, or provoking a discussion about divinatory practices. Kalinowski points out an existing affinity between predictive discourses and divination techniques, and he argues that oracular rhetoric in the Zuo zhuan may be comprised in its entirety as an expression of philosophical speculations through history writing, founded on the idea that only a Sage is able to predict the future. ${ }^{25}$

In the latest English language translation and study on the Zuo zhuan, Stephen Durant, Wai-yee Li, and David Schaberg argue that Chunqiu records had both a sacral quality, as being of concern to the ruler's ancestors, and a historical quality, as being of use to future policy makers and ritual practitioners. As for the role of the "commentaries" (interpretive traditions), such as the Zuo zhuan, the authors of the study believe that "the text is dependent upon its teachers, and particularly upon

24. Li Ling distinguishes four categories of historiographical materials: (1) genealogies—pudie lei 譜牒類; (2) annals—ji nian le $i$ 記年類; (3) archival documents—dang'an lei 檔案類; and (4) stories-gushi lei 故事類. He argues that (1) and (2) are related and can be denominated as shi ji 史記—“historical records." Similarly, (3) and (4) fall into the shi yu 事語 "narratives" category. Li Ling's theory regarding the relationship between Chunqiu and the Zuo zhuan is similar to Yang Bojun's; he too believes that the Zuo zhuan is a collection of old stories written independently by many authors and tailored to fit the Annals, and he agrees with Ban Gu that Confucius compiled Chunqiu and Zuo Qiuming edited the commentary based on it: Li Ling 李零, Jianbo gushu yu xueshu yuanliu 簡帛古書與學術源流 (Beijing: Sanlian, 2004) 260-79.

25. Kalinowski, "La rhétorique oraculaire," 39. 
teachers who, like Confucius, can maintain the true knowledge of the events behind the Annals's brief notations." ${ }^{26}$ This point emphasizes the special role of a Sage-teacher in the process of both transmitting historical knowledge and employing it as an oracle, and I will elaborate on it below.

The Chunqiu record of the capture of the lin is the first of seventeen entries made in the Annals on Duke Ai's fourteenth year (481 в.C.E.). The records go on for only two more years, till the death of Confucius in summer of Ai sixteenth (479 B.C.E.) - the last event recorded in Chunqiu. Later commentators interpreted the fact that the Sage's death brings the Annals to an abrupt end as an indication that Confucius is indeed the author of Chunqiu - the records expire along with him. However, both official commentaries on the Chunqiu一the Gongyang 公羊 and the Guliang 穀梁 traditions-end abruptly with the capturing of the unicorn, thus emphasizing the importance of that particular event.

Except for its placement in the Chunqiu, the capturing of the lin is just one of many recorded events, and it does not stand out among them in any way. However, considering the ritual character of the Annals-as a register of messages for the ancestors transmitted during sacrificial ceremonies in the temple- the entries are never random or accidental, and the mere fact that the event is included in it is significant; moreover, this is the singular mention of lin in the entire Annals. As I demonstrated in the discussion of the historiographical practice in Chunqiu, the event may have been recorded because it was considered anomalous, in which case it certainly involved the issue of timeliness.

The Zuo zhuan account of this occasion is very brief compared to Gongyang and Guliang traditions, as well as to regular Zuo zhuan entries-it tersely narrates what happened without providing any background information, interpretation, or commentary; it does, however, involve Confucius, which is an extraordinary circumstance. The Sage's mere assertion that the captured and injured animal is a lin is presented as being, in itself, meaningful enough, as if it did not require further explanation. " $\mathrm{Lin}$ " is not just a word, but also a powerful symbol. The hunters did not simply mistake one animal for another, but instead, due to their ignorance, they abused, and, effectively, profaned the unicornthe mythical portent of the returning Golden Age. Thus, the message of the text is quite clear: when the myth finally comes true, when the extraordinary turns into a palpable, common day reality, it is misinterpreted, mishandled, abused, and altogether wasted. As a matter of fact,

26. Stephen Durrant, Wai-yee Li, and David Schaberg, trans., Zuo Tradition: Zuozhuan 左傳 Commentary on the "Spring and Autumn Annals" (Seattle: University of Washington Press, 2016), xli-xlv. 
it almost goes unnoticed. Without Confucius, we would not know of the lin's appearance.

What kind of "recognition" does a lin require and how does one tell it apart from a non-lin? How does Confucius recognize it and why is it necessary that he point it out? Is a lin not a lin — can it not perform its function-if it remains unidentified? The unicorn would not be known without the Sage-it cannot reveal itself. On the other hand, Confucius would not be able to identify it if it were not a unicorn in the first place, thus being a thing self-evident and obvious; moreover, he would not recognize it if he himself were not a sage. Confucius discloses the identity of the unicorn, but at the same time the lin also confirms that of the Sage. In other words, the lin is not just a passive object of recognition, but also an effective agent. Thus, the Zuo zhuan passage reveals not only that a unicorn came, but also that Confucius identified it; moreover, it is the Sage who points out that it is necessary to ask: Why did it come?

The Zuo zhuan account does not contain more information, but its laconic language and the self-sufficient way in which the event is presented open doors to endless interpretation. According to Gongyang and Guliang, the capture of the unicorn is the last entry in the Chun$q i u$, after which the Annals are suddenly discontinued; both traditions provide longer accounts on the background of the event and, more importantly, put stress on Confucius's eminent role therein. Here, the Sage is not only depicted as identifying the unknown animal, but also lamenting its fate and contemplating the meaning of its coming. The Gongyang reports that, upon apprehending the lin, Confucius wept and proclaimed that its coming signified the end of his Way: wu dao qiong yi 吾道窮矣. The “Way”一dao 道—is better understood here as raison d'être: Confucius realized that he fulfilled his role as a Sage and that, at this point in time, he could do no more-no other unicorn was coming. The Eastern Han (25-220 C.E.) compilation Kongzi jiayu 孔子家語 elaborates that the Master deemed the coming of the lin "untimely"-bu shi-due to the absence of an “illuminated king" ming wang 明王—a “true" ruler possessing the power of discernment. In the Gongyang, too, Confucius exclaims: "For whom has it come?" shu wei lai zai 熟為來哉. As the text previously explains: “lin is a benevolent animal" lin ren shou ye 麟仁獸也， who "comes only when there is a king who acts as a king" you wang zhe $z e z h i$ 有王者則至. ${ }^{27}$

The coming of the Sage, just the same as the unicorn, is untimely. There is no ruler around ("a king who acts as a king") who would be able to truly appreciate Confucius and acknowledge his teaching. The

27. Legge, The Ch'un Ts'ew with the Tso Chuen, 834 . 
lin and its fate make Confucius understand his own position: he is aware of the fact that his time has not yet come, and that only in the future may he be recognized. At the same time, the Sage knows that his task has been fulfilled. His dao has reached a critical point-it has been manifested to the world. Confucius realizes his misplacement in time, which makes him understand that this is the crucial moment for him, the very point in time that defines, constitutes, and confirms his raison d'être. Therefore, the timing is both unsuitable and suitable: the Master does not lament his Way being lost, for it has actually been found in the future. The meaning of the "sage" - his teaching, and, indeed, Confucius himself-would not be what it is without its temporal aspect, signified and symbolized by the untimely coming of the unicorn.

Wai-yee Li observes that in the Zuo zhuan there is no "assertion of a necessary relationship between the capture of the lin and the creation of Chunqiu." ${ }^{28}$ Gongyang and Guliang traditions, however, do make this link, thus interpreting the episode as a turning point in the historiographical tradition. According to the former,

\section{制春秋之義, 以俟後聖。以君子之為, 亦有樂乎此也}

[Confucius] constructs the meaning of the Chunqiu in anticipation of later sages. Doing the work of a superior man, he also delights in this.

The Sage finds pleasure and hope in his work, trusting that it will be appreciated in the future; thus, his activity is oriented towards the generations that will come later, but his focus is on here and now-to do what a sage needs to do. ${ }^{29}$

When the Sage steps in, it is too late. He finds the proper terms to describe the situation, but he is aware that even as he does so, the sacred moment of epiphany had already passed. There is a paradox: the unicorn comes, and there is a sage able to recognize and welcome it, but instead things go astray-the lin is mistreated and killed; the Sage, on the other hand, recognizes the lin when it is too late to properly receive and save it. Thus, the potential of both the portent carried by the unicorn and the Sage's role in recognizing it seem to have come to naught.

28. Wai-yee Li, The Readability of the Past, 416.

29. Later commentators read this as a sign that Confucius foresaw the coming of the Han. Du Yu follows this school of thought and believes that Zhongni "used the Chunqiu of $\mathrm{Lu}$ to establish the teachings of moral-political revival; he stopped writing with the line on the capture of the lin because, having been moved to write because of it, he thus used it as an ending" (故因魯春秋而修中興之教, 絕筆於獲麟之一句, 所感而作, 固所以為終也). Ruan Yuan 阮元, Shisan jing zhushu 十三經注疏 (Beijing: Zhonghua, 1980), 6.59.11a. 
However, the coming of the unicorn, albeit untimely and tragic, reveals Confucius as the Sage and legitimizes his Way. Future generations will know him through the mere fact of identifying the lin, just as he knew the unicorn. Confucius and the unicorn complement, reveal, and reaffirm each other.

Chunqiu serves as a testimony-a tool by means of which Confucius sends the message into the future. According to the Guliang and Gongyang traditions, Confucius is inspired by this event to assume the role of historiographer-he resolves to scan the past in order to find out and pass on the events that led to the untimely coming of the lin. They present Confucius as the author of Chunqiu, motivated by the desire to illuminate and elevate the illustrious, and expose and condemn the unjust. In this way, these traditions identify Confucius with the shithe historiographers, diviners, and officers of ritual who analyzed and recorded events, explained anomalies, and communicated with the ancestors, thereby transcending the limits of time and space. As Waiyee $\mathrm{Li}$ concludes in her discussion of the Sage's encounter with the unicorn, "the ability to name the unknown, and the mastery of esoteric knowledge in general, constitute one of Confucius' images in Warring States texts." 30

The three accounts (Gongyang, Guliang, Zuo zhuan) of the capture of the $\operatorname{lin}$ all convey a strong sense of temporal displacement-things going amiss, a lost chance, events taking place in an unsuitable time and place. Confucius recognizes and identifies the $\operatorname{lin}$ as a powerful portent, and he sees the untimely coming of the mythical animal and its unfortunate fate as being emblematic of the present state of the society. In my reading of the tradition, the Sage turns toward the past in order to interpret the omen, and Chunqiu is the oracle that results. Confucius compiles the Annals as his commentary on the event-he reads the omen and then, in response to it, writes history. He is, at the same time, both the reader of the future - the prognosticator who understands the portent - and the writer of the past- the narrator who explains it.

In comparison, the narrative structure of the Zuo zhuan is more complex. Instead of Confucius, there are three figures that spin the historical narrative, the Narrator, the Prognosticators, and the Actors, who are correlated to form a temporal triad. The Zuo zhuan Narrator is situated in the future. He already knows the story. Inside the narrative, on the other hand, in the textual "here and now," there are the Prognosticators, who tell the story ahead of time by predicting the outcomes of the events. Lastly, there are the Actors, who are caught in between these two

30. Wai-yee Li, The Readability of the Past, 416. 
perspectives, and it is their history that is narrated as a prognosticated future. The perspective of Confucius, who scans the past upon beholding the future-as illustrated in the unicorn accounts-combines those of the Narrator and the Prognosticators. In the Zuo zhuan narrative, however, Prognosticators are the avatars of the Narrator planted in the text, making them, in effect, two different figures sharing one voice. This split perspective results in the production of a narrative in which the future is written in the past, and the past is written in the future. Through this narrative, the past meets the future and merges into one timeless "here and now." This narrative structure reveals the moral and political motives lying behind writing of history. The Narrator-historiographer assumes the position of a sage, who promotes certain historical figures as moral and political models to be followed. "History" is actually about the present and the future: there is a lesson to be learned from the past. In effect, the Zuo zhuan becomes a manual of socio-political know-how.

In his storytelling, the Zuo zhuan Narrator is restricted to a degree by the chronological course of real events and by the "historical facts" or what "really happened"; however, it becomes clear that his real job is not merely to report what occurred in the past, which he cannot change, but to explain its apparent paradoxes-situations when the law of punishments and rewards does not seem to have been working. To accomplish this, he employs three narrative devices: prognostication, paradox, and the spirit world.

Prognostication exposes the working of the Actors' fate; by planting Prognosticators in the plot, the Narrator breaks the boundaries and limitations of chronological time and realizes the efficacy of ming"sagely illumination." Justice will be served in the due time. Paradox, on the other hand, draws the readers' attention to the existence of a moral problem or conflict; then, by showing how the paradox unfurls and is resolved over time, the narrative assures the reader that the law of justice never fails. As for the deployment of spirit world, it is an issue for a separate study; here, it will suffice to mention that it foregrounds the punitive aspect of "sagely illumination" and signals its divine origins. The wronged Actors assume the role of "illuminated ghosts," ming gui 明鬼, in order to execute the justice; in effect, their own ming is revealed.

In illustration of these ideas, I offer as an example the story of Duke Wen of Jin. I will argue that the Zuo zhuan Narrator-just like Confucius-the-historiographer of the lin episode-understands his task of studying and representing the past to be that of looking for manifestations of ming, and that the criterion that he applies to this search is timeliness-shi. I will demonstrate that these two concepts undergird the logic of the narrative. 


\section{The Story-What Exactly Happened?}

The "Duke Wen Story" is the narrative presenting the affairs in Jin that led to the rise of Chong'er as Duke Wen of Jin. It consists of the accounts concerning the state of Jin that are scattered throughout the Zuo zhuan narrative over the period of time between Duke Zhuang twenty-eighth year and Duke Xi thirty-thirrd year. The entire history of Jin that emerges from these accounts is in fact centered on one man-Chong'er. Let us first consider the events, pieced together and arranged in a chronological order, as provided in the Zuo zhuan:

\section{a. Life of Duke Wen of Jin (666-628 в.С.E.)}

His name was Chong'er 重耳, and he was the son of Duke Xian of Jin 晉獻公 and the first of his Rong wives, Hu Ji 狐姬. Chong'er had an elder brother, Shensheng 申生, who was born of the incestuous relationship between Duke Xian and his late father's concubine, Qi Jiang 齊姜. Shensheng was acknowledged as the heir apparent. Chong'er also had a younger brother, Yiwu 夷吾, whom his father had with his second Rong wife. Thus, Chong'er was second in line to the Jin throne.

Later on, Duke Xian also married two daughters of the Li Rong tribe; one of them was called Li Ji 驪姬 and she had a son, Xiqi 奚齊. Li Ji became the duke's favorite, and she wanted to establish her own son as a successor to the throne; for this, she needed to oust the legitimate heir Shensheng and to eliminate his two brothers. She bribed two influential Jin officers to convince her husband Duke Xian to send his sons Chong'er and Yiwu away from the capital; the former was put in charge of $\mathrm{Pu}$ 蒲 and the latter of Erqu二屈, both cities on the border with the Di 狄 tribes. (Duke Zhuang, twenty-eighth year-Duke Min, first year)

She also managed to frame the heir apparent Shensheng for attempting to poison Duke Xian. As a result, he had to flee from the capital. Instead of trying to explain the matter to the duke or going into exile, Shensheng decided to commit suicide. This was an act of filial piety, because he declared that he sacrificed his life in order not to upset his elderly father by disclosing to him the truth about his beloved concubine. (Duke Min, first year-Duke $\mathrm{X} i$, fourth year)

$\mathrm{Li}$ Ji proceeded to slander Chong'er and Yiwu by accusing them of collaborating with Shensheng. As a result, Duke Xian, convinced that his sons had been plotting together, sent the army against $\mathrm{Pu}$. Chong'er, however, refused to fight against his father, and instead he fled to the Di. (Duke $\mathrm{Xi}$, fourth year-Duke $\mathrm{X}$, fifth year)

After the death of Duke Xian, Li Ke 里克, Pi Zheng 不鄭, and other followers of the three sons raised an insurrection; they killed the imposed heir apparent Xiqi-Li Ji's son—and attempted to install Chong'er as 
Duke Wen. However, by offering heavy bribes to Qin 秦 and gaining its support, the youngest brother Yiwu also managed to rise to power in Jin. Chong'er's followers tried to intrigue against him, but they failed, and in the end Yiwu was installed instead as Duke Hui 晉惠公. (Duke Xi, fifth year-Duke $\mathrm{Xi}$, ninth year)

Chong'er remained in exile for nineteen years. In the meantime, his brother Yiwu became an exemplarily bad ruler in Jin. He wronged Qin, provoked a war with it, was defeated three times in a row, and was taken hostage by the Qin army during the catastrophic battle of Han 韓. After many dramatic events, he was reestablished in Jin as his relations with Qin improved. (Duke Xi, ninth year-Duke Xi, fifteenth year)

After Duke Hui's (Yiwu's) death, his son Yu took over as Duke Huai 晉懷公; in order to prevent Chong'er from returning to power, the new duke passed new laws forbidding anyone to follow the latter; he also offered an amnesty period to all of Chong'er's followers should they decide to return. (Duke Xi, fifteenth year-Duke Xi, twenty-third year)

Chong'er spent twelve years of his exile among the Di and then passed through seven states before finally returning to Jin. He left behind the wife that he had among the Di. He passed through Wei 衛, where he was not properly received. In Qi 齊, he took another wife and fell in love with her, so much so that he refused to move on and his followers needed to trick him into leaving. Further on, he passed through Cao 曹, Zheng 鄭, and Chu 楚, and in the last state he had an agreement with the rival viscount. Finally, he got to Qin, where he gained support, enabling him to regain power in Jin. (Duke Xi, twenty-third year)

Qin restored Chong'er in Jin as Duke Wen 晉文公, and with Qin's help, he re-entered the state, defeated the Jin troops, and put to death Duke Huai. The Jin ministers, afraid of the new ruler's vengeance, tried to assassinate him, but the chief of the eunuchs switched his allegiance and warned the duke. Chong'er's Di wife arrived in Jin with their two sons.

Immediately after regaining power in Jin, Duke Wen began his reign by punishing all traitors and rewarding his loyal supporters and followers. He appointed only faithful and virtuous men as ministers. (Duke Xi, twenty-third year-Duke Xi, twenty-fourth year) His greatest accomplishment when in power was rescuing the exiled King and restoring him back in the Zhou 周 capital.

Duke Wen managed that single-handedly, without Qin's support, gaining merit and recognition. He obtained new territories for Jin, but not through force or conquest. (Duke Xi, twenty-fourth year-Duke Xi, twenty-fifth year) 
Duke Wen exercised power by appointing virtuous men, defending weaker states (he fought against Chu on behalf of Song 宋), and teaching and transforming the people by exposing them to his example. (Duke Xi, twenty-fifth year-Duke Xi, twenty-seventh year)

He fought and won a battle with Chu, after which the King officially declared him the hegemon of the states-ba 霸. (Duke Xi, twentyseventh year-Duke Xi, twenty-eighth year)

Duke Wen died after ruling Jin for nine years. During the funeral, there came out of his coffin a voice like that of an angry bull. (Duke Xi, thirty-second year)

He went down in history as a great hero, one of the five hegemons, $b a$, and a virtuous and illuminated ruler一ming jun 明君—compared to the sage kings of antiquity.

\section{b. The Narrative and the Supra-Narrative}

The plot of the story presented above develops in three chronological stages:

(1) The circumstances of Chong'er's expulsion from Jin and the reasons of the chaos that follows it;

(2) Chong'er's exile: He is not in Jin, and the narrative does not mention him, but only the affairs in Jin during his absence;

(3) Chong'er's triumphant comeback, his installment as Duke Wen, and the aftermath; the narrative here falls into two complimentary and interconnected parts: (a) the chronological and compact account of his nineteen-year-long odyssey leading up to his return to Jin; and (b) his return to Jin, his government of the state, and his attaining of the hegemony over the states.

At the same time, the story also contains three sub-stories:

(A) The story of Shensheng;

(B) The history of Jin's war with Qin under the rule of Yiwu/Duke Huai;

(C) The account of Chong'er's odyssey before returning to the throne in Jin;

These three narratives constitute separate story lines, which, themselves, can be subdivided into individual chronological stages, just the same as the main narrative that contains them. The three stories follow their own plots, but nonetheless fit into the "large" story of Duke Wen. 
The story has three main characters-Actors-the three sons of Duke Xian of Jin:

(1) Chong'er, who is the hero of the story; the narrative is about his way to hegemony;

(2) Shensheng, who is the martyr; he is the legitimate heir apparent in Jin, and it is through his sacrifice that the "hero" may succeed to the throne; he not only steps out of Chong'er's way, but also suffers an injustice for his sake;

(3) Yiwu, who is the "villain"; he is an imposter that obstructs the way of the hero;

As for the temporal structure of the narrative, Duke Wen Story unfolds on two levels-the narrative has two different modes of temporal progression, each corresponding to a different point of view:

1. The chronological level-the Narrative, where the events are unfolding progressively towards the future;

2. The historical level-the Supra-Narrative, where the story is completed and perceived in retrospect as history;

An anonymous Narrator, who already knows the story, tells it in retrospect, purportedly not changing any facts. He constructs the Narrative, where he presents the events in a linear and chronological way: Chong'er's birth, exile, return, success, and death. However, the Narrator is looking at the past from a perspective from which the story is already over and the outcomes have been revealed. From this perspective, Chong'er has already been established as a historical figure-Duke Wen-with the reputation of a hero and a sage ruler. The Narrator's job is to present how and when this happened. What made Chong'er a great hero? How was he able to return after nineteen years in exile and win hegemony over the states? Most importantly, from a politico-ethical standpoint, why was it legitimate for him to attain the position of duke in Jin, despite not being the rightful heir and even having killed Duke Huai, the legitimate successor of Duke Hui?

By way of elucidating such problems, the Narrator does not simply answer these questions; rather, he presents the events as an objective observer and never appears in the text "in person." The voice telling the story is always anonymous, and it does not overtly interpret or comment on the events. Instead, that is the task of the Prognosticators speaking from inside the Narrative-usually ministers or officers at court-who comment upon current events, pass their judgments, and foretell the outcomes. By predicting the future, they extrapolate the current, apparently 
spontaneous events from their chronological unfolding into the patterned, ethically legible Supra-Narrative. Likewise, the sub-stories that ostensibly focus on "individual" Actors eventually come together to demonstrate how their fates are interrelated and how they constitute the main story presenting the great hero. Thus, when narrating the stories of Shensheng and Yiwu, the Narrator is at the same time constructing a narrative on another level-the Duke Wen Story, which, from his perspective, pre-exists and overshadows the sub-stories as the Supra-Narrative.

The Supra-Narrative provides the final answers to the questions that arise from reading the Narrative. From the Supra-Narrative perspective, some situations in the Narrative seem paradoxical: (1) Shensheng-a virtuous man - suffers an injustice; (2) Yiwu remains ruler despite being an evil person; (3) Chong'er takes a long time to return and bring back the order, and despite being absent for nineteen years, he still manages to return and become a hegemon.

These paradoxes draw the attention of the Narrator and he sets out to explain them. For him, "what exactly happened" means: What caused the events to happen the way they did? Why things had to happen in a certain way? The Supra-Narrative is the perspective from which all the paradoxes are understandable.

Now, let us discuss the components of the story with a special focus on prognostications. I will first look at the Actors and what kind of narrative is used to present their lives-fates.

\section{The Actors and the Mechanism of Timeliness}

\section{i. Sub-story (A) - Shensheng and Temporal Displacement}

The first of the sub-stories (A) presents the apparently paradoxical fall of Shensheng, Chong'er's elder brother and Duke Xian's heir apparent in Jin. He is an exemplarily virtuous man, but despite that does not succeed to the throne. From the very outset, the Prognosticators constantly alert the reader that the heir apparent will not become a ruler. They also indicate that this turn of events is just and beyond the control of the Actor. On the Narrative level, then, Shensheng's fate is not fair; in the Supra-Narrative, though, it is justified and inevitable: the Prognosticators reconcile the paradoxes of the unfolding Narrative with the unimpeachable justice asserted by the Supra-Narrative.

When Duke Xian established his rule in Jin, he formed two armies, in defiance of the King's orders. ${ }^{31}$ He himself took command of the first

31. When giving investiture to the ruler of Jin, the King allowed him to maintain one army only (Duke Zhuang sixteenth year, 5); Yang Bojun, Chunqiu Zuo zhuan, 203. 
army and used it to launch a military expedition against three smaller states, and he made his eldest son and heir, Shensheng, the commander of the second one. The expedition was a success, and Shensheng with his army extinguished one of the three states. ${ }^{32}$ As a reward, the Duke sent him to preside over the capital city Quwo 曲沃.

These decisions are strongly criticized by the minister, Shi Wei 士蒍. Curiously, though, rather than Duke Xian, who was the actual decision-maker, he points at Shensheng as the one who will bear the consequences:

大子不得立矣。

The eldest son will not be installed [on the throne].

Shi Wei then predicts that Shensheng will be deposed:

分之都城, 而位以卿, 先為之極, 又焉得立?

He was assigned the capital [Quwo], and given the rank of the chief minister [as the commander of the second army]. Having prematurely been assigned the highest [rank], how can he then be installed [as Duke]? (Duke Min first year, 6).33

The minister explains that Duke Xian placed his son in charge of duties normally beyond the reach of one who is only, as yet, heir apparent. Because Shensheng had thus already occupied the highest positions in the state, his succession to the throne is blocked. By using the adverb "prematurely" - xian 先-Shi Wei does not mean that Shensheng was appointed too early in chronological time, but not in the right order. Duke Xian's decisions violated the rules of accession based on a proper sequence and hierarchy-the heir should wait for his time to take the control of the state.

In Duke Min second year (662 B.C.E.), the prediction that Shensheng will not succeed to the throne is further spelled out. His father orders him to wage war against the hostile Gaoluo 臮落 tribe. One Li Ke 里克—a court minister-remonstrates with Duke Xian that making the heir apparent an army commander is a stark violation of ancient rules. The officer lists the duties of the eldest son, or taizi 大子, and demonstrates that they are strictly ritual and representational; 34 making

32. Shensheng extinguished Huo 霍; the two other states-Geng 耿 and Wei 魏一 were extinguished by the army of Duke Xian. Yang Bojun, Chunqiu Zuo zhuan, 258.

33. Yang Bojun, Chunqiu Zuo zhuan, 258.

34. Bearing the vessels of millet for the great sacrifices, and for those at the altars of the land and the grain; inspecting the provisions cooked for the ruler every morning 
Shengsheng an army commander extends his power beyond what is appropriate, which undermines his position as an heir:

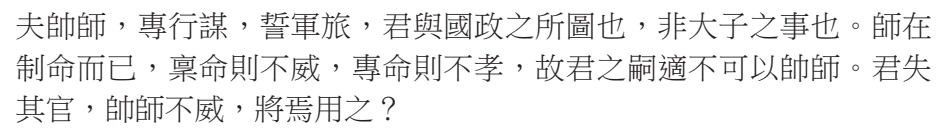

Leading the army, controlling its movements and strategy, and issuing commands to the troops are the tasks of the ruler and his chief minister, and not the business of the eldest son. Commanding [the army] is a matter of issuing orders; if [the heir] should receive orders [from someone else], it will injure his authority; but if he issues orders by himself, he will be unfilial. This is why the ruler's successor and heir cannot be in command of the army. The ruler will lose [the loyalty of] his officials, and the commander of the army will have no authority-how could one employ [the eldest son] [this way] him?

(Duke Min second year, 7) $)^{35}$

Li Ke understands that Duke Xian's actions amount to disowning and dooming his eldest son. The ruler is the commander in chief, and as such his responsibilities cannot be transferred to another. The heir apparent is only due to be a ruler after the present one is gone. Thus, Shensheng is being unfilial by assuming the powers of his father and, effectively, acting as if Duke Xian were dead. More importantly, though, he effectively acts as a ruler without actually being one; he technically becomes what he is only supposed to become in the future, ahead of his due time. This offence does not fall into the same category as a mere violation of one ancient rule, or even as committing a crime by symbolically deposing one's father and taking over his position; this is an offence against one's own self, enacted by impeding one's own future. The offence is, in essence, committed against the overarching value of timeliness. It is, after all, timeliness that determines who Shensheng is, as well as the moral value of his actions.

Before Shensheng departs for the expedition, Duke Xian equips him with an extraordinary parti-colored robe and a golden semi-circle hanging at his girdle; Hu Tu 狐突—the third Adviser, after Shi Wei and Li Ke, to prognosticate Shensheng's fate-interprets these as clear signs that the duke actually wants to doom his son. He explains that the marquis intends to destroy his son by manipulating time:

and evening; and guarding the capital when the ruler goes abroad (Duke Min second year, 7): Yang Bojun, Chunqiu Zuo zhuan, 268.

35. Yang Bojun, Chunqiu Zuo zhuan, 268-69. 


\section{時，事之徵也；衣，身之章也；佩，衷之旗也。故敬其事，則命以始； 服其身則衣之純; 用其衣, 則佩之度。今命以卒時, 閟其事也; 衣之起 服，遠其躬也；佩以金玦；充其衷也。服以遠之，以時閟之；㚭涼， 冬殺, 金寒, 玦離, 胡可恃也? 雖欲勉之, 狄可盡乎?}

The season is the emblem of an activity; the dress is the "stamp" of a person; the girdle is the manifestation of the heart. If [the Duke] had accorded due regard to the affair, he would have ordered it at the beginning of the year; ${ }^{6}$ dressing the prince, he would have picked for him a robe of one color; and if he were sincere, he would have picked a proper degree for the girdle. Now, the orders come late in the year, which means that [the Duke] wants to impede the affair; having him dressed in a parti-colored robe shows that he wishes to remove and distance his son's person from himself; having picked a golden semi-circle for the girdle indicates that he discards kindly feelings. He distances [his son] by means of the robe [in which he dresses him]; and he impedes his actions by means of the season [that he picks for the campaign]; the season shuts the prince up from success; the parti-colored [garment] cools; the winter kills; the metal chills; and the symbol-semi-circle-lacks; what is there to be trusted to and relied upon? Even if the prince tries to do his best, can the Di be utterly destroyed?

$(\text { Duke Min second year, } 7)^{37}$

The minister is convinced that Duke Xian intentionally appoints Shensheng to command the army, sends him out on an expedition in the wrong season, and endows him with suspicious insignia, in order to doom him. In his interpretation, $\mathrm{Hu} \mathrm{Tu}$ focuses on the symbolic and moral aspect of the situation; as he emphasizes, the time/season is what allows a certain kind of activity. Each season indicates what kinds of activities are timely, and therefore appropriate. There is also an underlying practical side: the season Duke Xian chose may be too cold for the expedition. The meaning of shi is multivalent-it means "time" and "season," but also "weather." All of these categories are closely related with Nature, marking its course, and fall under one heading of "timeliness." As another minister, Xian Danmu 先丹木, points out, the duke gave Shensheng orders that are impossible to follow:

36. Shi 始 here indicates the first half of the Chinese year-spring/summer; Duke Xian is sending the expedition in winter (second half of the year- $z u$ 卒), which is not the right season: Yang Bojun, Chunqiu Zuo zhuan, 270.

37. Yang Bojun, Chunqiu Zuo zhuan, 270-71. 


\section{曰：‘盡敵而反’ ; 敵可盡乎?}

[The duke] said: "Only after destroying the enemy completely may you return"; but can the enemy be completely destroyed?

(Duke Min second year, 7) ${ }^{38}$

The expedition is unseasonable and the insignia Shensheng received are inappropriate. Xian Danmu anticipates that it will be impossible for the heir to successfully carry out such definitive orders. Even if Shensheng wins the battle, under no circumstances will he be unable to "completely" destroy the enemy; therefore, when he returns home, he will have effectively, if unwittingly, contravened the will of his father, giving his father reason to call him unfilial and consequently disown him. He cannot quit the expedition, nor can he successfully carry it out; therefore, as other ministers at court observe, the heir is put in a position where however he acts, he will end up either being unfilial or unfaithful. 39

The Prognosticators reveal that Duke Xian dooms his son by displacing him in time. Hu Tu's assessment that "the season is the icon of an activity" renders Shensheng "not valid"-he is "not allowed" in the season, and thus "unseasonable." All his official appointments, as well as the battle to which he is about to lead the army, are untimely. As an heir apparent, as a man of virtue, and as a son, he is completely dislocated, finding himself at a wrong place and at a wrong time. Despite being a virtuous man and having done nothing wrong, Shensheng is prevented from becoming the ruler of Jin. Thus, the prognostications confront the reader with a paradoxical situation-how do we explain this undeserved fate?

In the first prediction that Shensheng will not succeed to the throne, the officer Shi Wei makes it clear that the heir is merely an innocent scapegoat and directs the criticism at his father. The minister even offers a solution for Shensheng:

\section{不如逃之, 無使罪至。為吳大伯, 不亦可乎? 口猶有令名, 與其及也。 且彥曰：『心苟無瑕，何恤乎無家？口』天若祚大子，其無晉乎？}

He would do better to escape [to another state], and not let the charge of guilt catch up with him. Would it not be just right for him to be like

38. Yang Bojun, Chunqiu Zuo zhuan, 271.

39. The officer Yangshe 羊舌 says, "[If the heir] disobeys [his father's] orders, he will be unfilial; if he abandons the affair, he will be unfaithful" (違命不孝, 棄事不忠) (Duke Min second year, 7): Yang Bojun, Chunqiu Zuo zhuan, 272. 
Tai Bo of $\mathrm{Wu}$ ? $^{40} \mathrm{He}$ will still maintain a good name: - how much better than [to stay and] let calamity come on him! Moreover, as the proverb says, "If one's heart has no flaw, what need he regret having no home?" If Heaven [had meant] to confer dignity on the eldest prince, would there then have been no Jin for him?

(Duke Min first year, 6) ${ }^{41}$

Thus, Shensheng is not to be punished. A virtuous man who did no wrong, Shensheng has nothing to fear. However, he cannot escape being deposed: it is independent from Shensheng's moral standingwhether he is good or bad, right or wrong-but instead it is entirely determined by timeliness. The moral censure, on the other hand, is not inevitable: Shensheng can save his good name and be free of the "charge of guilt." Following orders will lead him into the temporal trap set up by his father, which will result in death, but he will not be the guilty one. Escaping the trap and saving his life, on the other hand, involves disobeying his father; consequently, he will be forced to bear the charge of guilt. He will be deposed either way, but he has the option of saving his life versus his name. Thus, the dilemma Shensheng is facing is of a moral nature, and he must decide which action is morally more desirable.

The ministers-Prognosticators provide Shensheng with clear moral guidance. Li Ke says:

子懼不孝, 無懼弗得立, 修已而不責人, 則免於難。

As a son, you should be anxious of being unfilial, rather than of not being installed; cultivate yourself instead of blaming others, and you will escape calamity. (Duke Min second year, 7$)^{42}$

Yang She 羊舌 advises:

雖知其寒, 惡不可取, 子其死之.

40. In Analects VIII, 1, Confucius presents Tai Bo, the eldest son of King Dan of Zhou who renounced the throne thrice in favor of his youngest brother, as an example of moral virtue: "The Master said: 'Of Tai Bo it may indeed be said that he attained to the very highest pitch of moral power. No less than three times he renounced the sovereignty of all things under Heaven, without the people getting a chance to praise him for it.'” (子曰：「泰伯, 其可謂至德也已矣! 三以天下讓, 民無得而稱焉。」) He fled and wandered around Wu and Yue, two states still considered "barbaric" in early Zhou times: Yang Bojun 楊伯峻, Lunyu yizhu 論語譯註 (Beijing: Zhonghua, 1980), 78.

41. Yang explains that the text is corrupt here and reads instead: 與其及也, 不如逃 之, 無使罪至。為吳大伯, 不亦可乎? 猶有令名; 及 refers to 罪: Yang Bojun, Chunqiu Zuo zhuan, 259.

42. Yang Bojun, Chunqiu Zuo zhuan, 269. 
Although you know his [your father's] cold feelings, you must not choose evil [and disobey him]; better you should die for it. (Duke Min second year, 7$)^{43}$

Lastly, in his final words of advice for Shensheng, $\mathrm{Hu} \mathrm{Tu}$ admonishes the prince:

今亂本成矣, 立可必乎, 孝而安民, 子其圖之, 與其危身以速罪也。

The root of disorder has already been formed [in Jin], so can your succession to the throne be certain? Being filial and pacifying the people should be your plan and strategy; this will be better than putting your person in danger by accelerating the charge of guilt.

(Duke Min second year, 7$)^{44}$

In Duke Xi fourth year (656 B.C.E.), we can see Shensheng's end. Li Ji slanders him of attempting to poison Duke Xian. The ministers urge the prince to explain the matter to the marquis, but he does not want to upset his father by disclosing to him the manipulations of his beloved concubine. He also refuses to flee to another state, because this would mean admitting to the crime and living in disgrace. In the end, Shensheng takes his own life; he dies as a martyr of virtue and filial piety.

As Shi Wei points out, Heaven is doing Shensheng a favor by providing an opportunity to prove his virtue and to find a more suitable place for himself. By putting Shensheng in line with Tai Bo-who was a paragon of moral virtue praised by Confucius in the Analects-Shi Wei expresses his admiration of the prince. The minister may deem the prince unfortunate and wronged, but certainly not guilty and doomed. There is a strong suggestion in Shi Wei's judgment that Shensheng belongs to a different time and place.

If Shensheng is Tai Bo, then control over his fate lies in making his own moral choice. He must understand that he is not the right person for the time and that the future does not belong to him. There is another heroruler yet to come, and Shensheng needs to remove himself from his way, so that the rules of timeliness are observed and justice may be served. As Shi Wei points out, Shensheng would have been able to escape his punishment by death; however, he follows the advice of the Prognosticators, and understands that a sacrifice like that made by Tai Bo-which allows the "timely" ruler to come-is morally more desirable.

43. Yang Bojun, Chunqiu Zuo zhuan, 272.

44. Yang Bojun, Chunqiu Zuo zhuan, 272. 
From the perspective of the Supra-Narrative Shensheng has to remove himself, because he needs to make room for Duke Wen: if Shensheng became ruler, Chong'er would never make it to the throne. The Narrator in the Supra-Narrative needs to justify the wrong Shensheng will suffer by presenting it as a sacrifice. The Narrator-through the Prognosticators-clearly puts the blame on Duke Xian, and indirectly on Li Ji, who actively proceed within the Narrative to oust the legitimate and innocent heir apparent. The general law of punishments and rewards seems to be neglected or abused here, since the injustice happens to a virtuous man; however, the logic and rationale that the Narrator fosters is timeliness, which is not within the capacity of the Actor to decide, but it is for him to know and to follow. In other words, Shensheng does not have the power to determine his time; instead, he is a misplaced virtuous man, and he cannot prevent his doom. Duke Xian, embodying the mechanism of timeliness, destroys him by means of time- -he makes time work against Shensheng.

On the Narrative level-from the point of view of "what happened"-Shensheng is mistreated and wronged. But on the Supra-Narrative level, his ostensible "doom" emerges as a necessary sacrifice to the Hero-Duke Wen. Rather than becoming a refugee and a partisan, Shensheng follows the example of Tai Bo and volunteers his birthright. The desire to save his own name and to spare the feelings of his father are not the only motifs of Shensheng's suicide; his ultimate goal is to support Chong'er. Thus, Shensheng understands the workings of time and, consequently, knows the future-the inevitability of his younger brother becoming Duke Wen. Therefore, he consciously and actively enables it.

On the Supra-Narrative level, though, Shensheng does get his reward-Shi Wei compares him to Tai Bo, thus elevating him to the position of the sages. From this perspective, then, things do make sense, and they are just - the right things come in the right time; "timeliness" is in itself the validity of the thing. Duke Wen is due, Shensheng is notsuch is the timely design. Shensheng embraces his fate and does not act against time.

\section{ii. Sub-story (B)-Yiwu and the Historical Doom}

All the accounts of the events in Jin under Duke Hui (Yiwu) have the same narrative structure: they consist of the historical account itself-a report of what happened; and an additional part that could be classified as a "commentary" or a judgment-a record of an opinion articulated by a person witnessing the situation, which invariably is a prediction of Duke Hui's imminent doom. There is not a single entry in the whole 
narrative covering the affairs in Jin during that period that would not serve as a pretext for a judgment upon Yiwu's actions and a foretelling of their consequences. These predictive comments 45 serve as a narrative device, by means of which every event presented in the text is portrayed as a transgression committed by Yiwu as Duke Hui.

The narrative consists of episodes depicting to major events that lead to Yiwu's doom: (1) In response to the killings of the two consecutive successors of Duke Xian, ${ }^{46} \mathrm{Qi}$, as the hegemon of all the feudal states, leads a military expedition in order to put an end to the disorder in Jin. Yiwu, the younger brother of Chong'er, takes advantage of the chaos to usurp the throne, and offers bribes to Qin to win its support; Qin enters Jin and together with Qi installs Yiwu as Duke Hui (Duke Xi ninth year); (2) Duke Hui starts off by executing Li Ke-Chong'er's follower, but also the very man who enabled Yiwu's own ascension to the throne; (3) Next, he proceeds to re-inter the body of his late brother, Shensheng, who was buried improperly, thus pretending to honor the latter and make up for the injustice done to him. In connection with this, the ghost of Shensheng appears to the minister $\mathrm{Hu} \mathrm{Tu}$ and informs him of his plan to have the Lord on High—di 帝—doom Jin and give it over to Qin. This is supposed to be the punishment for Yiwu's transgressions. Hu Tu manages to talk Shensheng out of this idea; so, Shensheng decides to punish only Yiwu; (4) Pi Zheng, another loyal follower of Chong'er, travels to Qin and tries to scheme against Yiwu. The intrigue fails, and Pi Zheng is executed, along with seven other officers associated with him (Duke Xi tenth year); (5) In the following year, the king of Zhou legitimizes Yiwu as Duke Hui of Jin. Reportedly, the latter behaves disrespectfully when receiving the mandate (Duke Xi eleventh year); (6) Jin suffers from scarcity and asks Qin for grain. After some hesitation and debate, the Earl of Qin decides to relieve Jin (Duke Xi thirteenth year); (7) Mount Shalu 沙鹿 collapses (Duke Xi fourteenth year); (8) In a year of scarcity in its own territory, Qin asks Jin for grain, but Duke Hui refuses to relieve his neighbor and benefactor (Duke Xi fourteenth year); Duke Hui breaks all the promises he gave to the Earl of Qin and to several officers in Jin. In addition, he commits adultery with the late Duke Xian's concubine, a woman related

45. I use "predictions" and "predictive comments" as general terms that include all kinds of projections of the future: they can be actual prognostications based on divination, but also warnings and calculations of the ministers based on their analysis of current politics, personal experience or knowledge derived from books. As becomes evident in the narrative, all the warnings and advice given by the ministers come true, and they invariably prove Yiwu wrong; therefore, they should be read as foretelling of the future. For a comprehensive review of the types and classification of prediction in the Zuo zhuan, see Kalinowski, "La rhétorique oraculaire," 46-47.

46. Xiqi 奚齊 and Zhuozi 卓子, both sons of the Rong concubines. 
to the house of Qin; (9) Duke Hui's dishonesty and unfaithfulness upset the Earl of Qin, and he decides to invade Jin; (10) Qin forces defeat Jin three times in a row and meet its army for the final battle on the plains of Han. Duke Hui ignores good advice, and against all reason and principle, forcefully confronts Qin. He appoints bad assistants and uses inadequate horses for his chariot. His minister and chief adviser, Qing Zheng 慶鄭, abandon him on the battlefield and, as a result, the duke is taken captive and carried away to Qin. The officers of Jin express loyalty to their ruler; they follow him into captivity, submit to their fate, and are ready to die along with the duke, thus indicating to the Earl of Qin that by putting to death Duke Hui he will be responsible for the death of all of them. The Qin earl's wife Mu Ji 穆姬, in defense of her brother一the ruler of Jin-threatens to commit suicide along with her children; therefore, the earl promises to do no harm to Yiwu and decides to reestablish him in Jin. He has an agreement with Jin, according to which the Yiwu's son and heir be sent to Qin as a hostage. In the end, Duke Hui returns to his state, whereupon Qing Zheng is put to death. When Jin suffers from scarcity, Qin once again relieves it with grain. The Earl of Qin abandons the idea of annexing Jin, but he nevertheless appropriates some of the latter's territories to the east of the river. (Duke Xi fifteenth year) Duke Hui dies eight years later. His son Yu manages to escape from Qin and takes over the Jin throne as Duke Huai. (Duke Xi twenty-third year)

As mentioned above, every event in Jin narrated in the text can be linked with a corresponding (negative) prognostication:

(1) With the help of Qin army, Yiwu is installed as Duke Hui in JinThe Earl of Qin discusses with his ministers the situation in Jin; Gongsun Zhi 公孫枝 declares that Yiwu will not manage to settle the state. (Duke Xi ninth year)

(2) Yiwu puts to death $\mathrm{Li} \mathrm{Ke}$ - The new duke does this, because he does not feel secure and, seeing it coming, attempts to prevent his own doom.47 (Duke Xi tenth year)

47. This is not a prediction per se, but a reflection of Yiwu's own anticipation of the doom and an attempt at preventing it. The text says that he puts Li Ke to death "to redeem himself" (以說), which Yang interprets as "making an example of punishing the evil" (示討惡之義). Yiwu pretended he was punishing Li Ke for the murders of his two step-brothers and enthroned Jin rulers; in other words, Li Ke was serving as his scapegoat, so that Yiwu would be cleared of the complicity. In the message Yiwu sends to Li Ke, he admits that he owes him his current position, but also confesses his fears, saying: “it would be difficult/disastrous to be your ruler" (為子君者, 不亦難乎?). Thus, the real motive of his action is insecurity-he sees in Li Ke's actions the reflection of his own; therefore, he knows what he himself would have done if he were in Li Ke's 
(3) The Shensheng episode-The ghost of Shensheng promises that he will punish Yiwu. He declares that the Duke Hui will be defeated in Han. (Duke Xi tenth year)

(4) Execution of Pi Zheng and his associates-One of the men to be executed, Pi Bao 丕豹, escapes to Qin and predicts that Duke Hui will find no support in the state. He urges the Earl of Qin to take action and expel Duke Hui. (Duke $\mathrm{Xi}$ tenth year)

(5) The King sends Duke Wu of Shao 召武公 and the Historiographer of the Interior neishi Guo 內史過 to confer the mandate-ming 命—on the new marquis of Jin; the latter receives it "indifferently/carelessly" — duo 惰. Upon return to the court, the neishi, in his conversation with the King, predicts that the marquis's successor will not be his own son. (Duke Xi eleventh year)

(6) Scarcity in Jin: the Earl of Qin consults his ministers about the idea of sending relief grain to Duke Hui. Zisang 子桑 anticipates the Jin marquis's duplicity and predicts his future alienation and defeat. (Duke Xi thirteenth year)

(7) The collapse of a mountain in Jin-The diviner $b u$ Yan 卜偃 predicts that by the end of the year there will come a great calamity, which will nearly put an end to the state. (Duke Xi fourteenth year)

(8) Scarcity in Qin-the earl asks Jin for relief, but Duke Hui refuses to return the old favor. Qing Zheng points out his error to the duke and warns him of losing the state, being abandoned by the supporters and rejected by the people. The minister also emphatically declares that the marquis will regret his decision. (Duke Xi fourteenth year)

(9) Qin invasion-Diviner shi Tufu 徒父筮 of Qin divines about the expedition predicting that Jin shall be defeated three times and that the marquis of Jin shall be captured. (Duke Xi fifteenth year)

(10) The battle of Han-The marquis ignores the divination concerning the appointment of his right spearman; he also ignores

position. More importantly, though, Yiwu's deed discloses him as a hypocrite and a usurper. In his response to Yiwu's message, Li Ke makes it clear: "If not for [others] having been removed, how would you have risen?" (不有廢也, 君何以興? ) The episode is not exactly a projection of Yiwu's future, but it is certainly not presenting him favorably. Rather, it is another example of a transgression that is being used against him. Thus, it fits into the overall scheme of the narrative aimed at disparaging Yiwu. See Yang Bojun, Chunqiu Zuo zhuan, 333. 
Qing Zheng's advice concerning the horses for his chariot. The latter predicts the horses' behavior and declares that the marquis will regret his actions. (Duke Xi fifteenth year)

As we can see, the narrative draws a portrait of Yiwu as one who only commits transgressions and ignores all warnings and good advice. Finally, the prognosticated doom does come: he provokes a war with Qin, is defeated in the battle of Han, and is taken captive. However, all this amounts to another paradox. After such an intense, consistent, and relentless criticism of his person in the text, it comes as a surprise that Yiwu is not finished, but instead all the people in his state unite and stand up for him, and in the end he is restored and able to continue as Duke Hui. Once again, the reader's sense of justice is disturbed; there is certain opacity about Yiwu's "doom," which seems pallid and makes one suspect that it has not been quite completed yet.

The steady accumulation of negative prognostications indicates that this is not Yiwu's time to be the ruler. He appropriated someone else's time - he stole it —and he will be punished. Thus, the prognostications expose him as a usurper and draw the reader's attention to the legitimate ruler-Duke Wen.

Noticeably, the narrative covering the rule of Yiwu in Jin begins and ends with references to Chong'er. At the beginning, when Duke Xian dies, two Jin officers, Li Ke and Pi Zheng, raise an insurrection against Xiqi, the son of Li Ji and the appointed heir; they mobilize all the supporters of the late marquis's three "legitimate" sons against the intruders imposed by Li Ji's intrigues. Their aim is to enthrone Chong'er.

However, the text says that they want to "install Duke Wen." This phrasing, at this early moment, is portentous. The text refers to Chong'er as "Duke Wen," as if he had actually become the successor of Duke Xian and the legitimate ruler of Jin. The following account of the events, however, seems to prove otherwise. Yiwu ousts Chong'er before he is installed. After the murder of Xiqi, who is never referred to as "duke," the party supporting the two Li sisters wants to raise Xiqi's half-brother Zhuozi 卓子, but Li Ke kills him as well. The chaos in the state provokes the intervention of Qin, and with their help and support, younger brother Yiwu ousts Chong'er and is installed in Jin as Duke Hui. Thus, Chong'er does not become "Duke Wen" when he returns to the state after Yiwu's/Duke Hui's death, and before then he is only known as "Chong'er."

The proleptic phrasing used in the narrative is a deliberate choice. The Narrator, who knows how the story is going to unfold, reveals to the reader the events that are going to take place in the future. Thus, the reader learns that Chong'er is not disappearing for good, his story is not 
over, and he shall return and take over the throne in Jin. Also, referring to Chong'er as "Duke Wen" determines the way the reader perceives Yiwu, undermining, in narrative terms, his position as Duke Hui. From now on, he will be regarded as a usurper and, more importantly, as a temporary ruler, a resident, who occupies the throne during the time of transition. The "real" ruler is waiting for his time, his story pending.

The fact that Yiwu is not the genuine ruler is established in the narrative immediately following his installment in Jin as Duke Hui. The Earl of Qin consults his minister Gongsun Zhi about the situation in Jin and whether Yiwu will manage to settle the state. $4^{8}$ Gongsun Zhi replies:

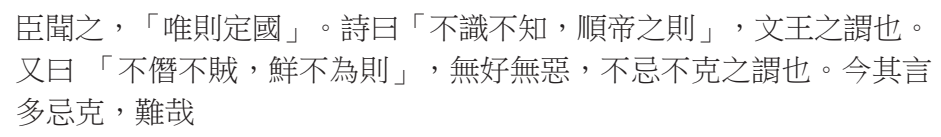

Your servant has heard that "the state can be settled only by following the model." As "The Odes" have it, "Unconsciously and unknowingly, he adjusts himself to the model of the Lord on High," which is said of King Wen. Also: "There are few of those who do not usurp nor steal, and who do not serve as a model," which is said of him who has no likes nor dislikes, and who is not jealous nor ambitious. As for now, [Yiwu's] words are full of jealousy and superiority, so it is going to be rather hard [for him to settle the state].

(Duke Xi ninth year, 6)49

The minister juxtaposes Yiwu with King Wen 文王, the sage ruler of Antiquity, and presents him as his counter-example-an anti-ruler. The convergence of names-King Wen/Duke Wen-is not a mere coincidence. It indicates that Chong'er possesses all the qualities attributed in the text to King Wen, and therefore he deserves to later become a hegemon - $b a$, and an illuminated ruler-ming jun. The text establishes him as Duke Wen, even though his time has not come yet; Yiwu, on the other hand, is portrayed as his exact opposite and alter ego. Here and now, his words are false, and he is bound to be doomed.

Without mentioning him, Gongsun Zhi, then, playfully refers to Chong'er by comparing Yiwu to King Wen. The latter derives his capacity as a ruler from the Lord on High, di; thus, his sagehood is of a divine

48. 夷吾其定乎; the interrogative particle $h u$ 乎 implies doubt. This is important, because being able to "settle the state" and bring harmony to the people (the Earl of Qin first asks if Yiwu has support in the state) are the two basic requirements of a sage ruler (ming jun).

49. Yang Bojun, Chunqiu Zuo zhuan, 331. 
origin. He is molding himself after Heaven without effort or consciousness; he does not aspire, he is a genuine king.

The effect of the narrative is to show that there is no way Yiwu could claim that, even if he manages to take the throne. Although he completes his turn, he never fulfills the requirements of a sage ruler, such as settling the state or gaining the recognition of the people. His mission is not divine, and the time does not belong to him-it belongs to Chong'er, who already is Duke Wen, despite the fact that he has not yet been formally established. The time covered by the Narrative is not the duration of Duke Hui's rule in Jin, but that of Chong'er's absence.

Gongsun Zhi deems Yiwu "envious and ambitious" ji ke 忌克. The Earl of Qin develops this thought and says in reply:

\section{忌則多怨, 又焉能克?}

He is jealous, therefore many will resent him; how can he ever achieve [what he desires]? (Duke Xi ninth year, 6) $)^{50}$

King Wen, and thus Duke Wen/Chong'er-as implied through the parallel—acts spontaneously and is impartial. He has neither envy nor ambition, he does not need to do anything in order to be who he is, and his appointment is divine and timeless. Yiwu, on the other hand, being jealous of his elder brother, aspires to take his place; but even while he occupies the throne as Duke Hui, it is Duke Wen who is the legitimate ruler. Yiwu cannot achieve through force what is granted from Heaven.

Therefore, Yiwu's return to Jin after the battle of Han and the captivity in Qin is not an achievement; neither are the following eight years as Duke Hui, of which the Zuo zhuan provides no account. He does not redeem his name and position. He is restored-through the agency of someone else-just for the time being.

It was Earl of Qin who decided to release Yiwu from captivity and reinstall him in Jin. He explains why he decided so-rather than extinguishing Jin — and with this assessment the Zuo zhuan narrative concerning Yiwu ends:

吾怨其君，而務其民。且吾聞唐叔之封也，箕子曰：「其後必大。」 晉其庸可冀乎? 口姑樹德焉, 以待能者。

I resent [Jin's] ruler, but I do sympathize with its people. Besides, I heard that when Tangshu ${ }^{51}$ was enfeoffed, the viscount of Qi said: "His descendants will surely flourish." How, then, would I be able to annex

50. Yang Bojun, Chunqiu Zuo zhuan, 331.

51. The progenitor of the Jin lineage. 
Jin? For the moment I shall cultivate my virtue and wait for a capable man to arise [in Jin]. (Duke Xi fifteenth year, 8)

Clearly, the Earl of Qin respects the predictions and has a strong notion of timeliness. He resists personal sentiments-betraying no likes or dislikes-and, even though it seems Jin is entirely under his control, he adjusts his actions to Heaven's design. He does not take advantage of his power, because he knows the future. He understands that there is a right moment for each action, and that acting against time would be futile. The Earl remembers the prediction that Tangshu's descendants will flourish, and thus knows that it is only a matter of time before a capable ruler arises in Jin. He, in fact, knows who that ruler is, and this is another hint at Chong'er's imminent return.

As I pointed out above, it is noticeable that after Yiwu's restoration in Duke Xi fifteenth year, there are no accounts in Zuo zhuan of affairs in Jin until Duke Xi twenty-third year, when he dies a natural death. The fact that each narrated event is associated with a criticism, a condemnation, or a prediction of his doom, shows that they are reported only when they can be used against Yiwu, and, indeed, in order to discredit him. On the other hand, we are not told what is happening in Jin during the last eight years of his rule; evidently, it is irrelevant from the point of view of the Narrator, who shapes the account according to his larger plan. The absence of narrative is meaningful and it constitutes a part of the portrait of Yiwu drawn by the Narrator; it is also important for a correct understanding of the nature and significance of his doom. Qin allows Yiwu to complete his turn as Duke Hui; however, his fate is no longer in his hands, and he does not have the power to change his status. He has no future and no present, either, already being consigned to oblivion. Hence, after his return to the throne, there are no further accounts and no predictions concerning him. No text is necessary. His story is over, and his doom is sealed. The future, the time, and the story belong to Duke Wen, who will come in due time.

Initially, as in the case of Shensheng, the narrative presents a paradox: evil seems to be prevailing over good and an exemplarily bad ruler successfully takes the place of and delays the coming of a good one. This narratological strategy is meant to explain and justify the belated coming of the Hero. The Narrator has to comply with the fact that Yiwu-a usurper who from the Supra-Narrative point of view obstructs the way of Duke Wen-successfully stays on the throne and completes his turn; however, by carefully selecting the events to be narrated, the Narrator is able to portray him in an unfavorable way and present as a counter example the main-temporarily "hidden" — protagonist of the narrative. 
Shi Wei compares Shensheng to Tai Bo, thus clearly indicating that the heir is not being deposed, but instead, is consciously yielding the throne to his younger brother, Chong'er. The parallel is at the same time an exaltation of Shensheng and a prediction of Chong'er's accession to the throne. It also juxtaposes Shensheng and Yiwu as two opposite examples, where the former clears the way for Duke Wen, and the latter obstructs it.

By putting him in line with Tai Bo, Shi Wei is aligning Shensheng with an archetype, thereby taking him out of the chronological flow of history - the Narrative-and, by extension, away from his own doom. He enters the Supra-Narrative and becomes a model, just as Chong'er, who-in comparison to King Wen-is Duke Wen even before he ascends the throne in the chronological narrative, thus escaping it. Shensheng is exalted-and saved - by "history" (as seen from the perspective of the Narrator-the Supra-Narrative), while Yiwu is doomed by it. As I pointed out above, the latter does not meet his final punishment in the chronological narrative, but instead by his portrayal as a negative character, which is clearly visible from the Supra-Narrative perspective.

A question arises: If a certain kind of future is inevitable, then is Shensheng's choice really a choice? He knows his fate and concedes to it, because he is aware that acting against it is futile, just like the Earl of Qin. He cannot change the future, nor by extension, his own fate; however, he does have a choice between right and wrong. Shensheng cannot become a ruler in Jin, because his "coming" is untimely, but he can determine his standing in history as a virtuous man by making the right choice between enabling the coming of Duke Wen and trying to prevent it.

Making the right choice is not merely efficacious or even moral; rather, it demonstrates the sage-like ability to see things clearly: the quality of ming. Unlike Shensheng, Yiwu is unaware of the workings of time and, consequently, of the future. Therefore, Shensheng may suffer a temporary injustice, but ultimately he wins-he is the moral victor. He heeds good advice, understands the working of time and the imminence of justice; therefore, in this fundamentally moral sense, he can read the future. Possessed of "sagely illumination" ming, Shensheng is proclaimed to be just like the sage Tai Bo. He is rewarded by history with the name of a virtuous man.

Yiwu, in contrast, occupies the throne of Jin and dies a natural death; he temporarily wins, but he loses his future, his moral standing as determined by the writers and readers of history. Yiwu does not heed advice, he ignores the prognostications, and he acts against time. As a result, he is portrayed as the counter example of a sage. He lacks "sagely illumination," and he is-quite literally-erased from history. Such is his final doom and punishment. 
Thus, the Narrator uses prognostications to explain why Shensheng does not get the throne, as well as to present Yiwu as an illegitimate ruler. Ultimately, they enable and justify Chong'er's return after his long absence, demonstrating that sooner or later justice is served.

The narrative that bears out the prognosticated fates of Shensheng and Yiwu endorses Chong'er in absentia; and, paradoxical situations that seem to suspend the law of justice only heighten the expectation of justice to come.

\section{iii. Chong'er and the Rhetoric of Silence}

Unlike the actions of Shensheng and Yiwu, those of Chong'er are never commented upon, and (in the Narrative) he is offered no advice. All the prognostications concerning him are about him, not for him, and they prepare the reader for his return as Duke Wen. The narrative seems designed to generate in the reader a sense of anticipation, even before Chong'er's exile is shrouded in silence. Chong'er is slandered by their evil stepmother and wronged by his father. When he has to leave the capital and is eventually forced out of the state, he is completely absent from the narrative until his return nineteen years later. The story of Chong'er is hidden from the reader, but unfurls in silence simultaneously with the narrated current of events in Jin. His name is never mentioned, but the reader is regularly reminded that Chong'er's story is not over and that he is going to come back.

The first part of Duke Wen's story establishes him as a man of virtue. His expulsion from Jin is clearly unjust. By refusing to fight against Duke Xian, Chong'er presents himself as a filial son and a loyal subject; that is, he is in the right. He humbles himself and sacrifices for his father and ruler. It is questionable whether he has enough strength and support to successfully defend himself in $\mathrm{Pu}$ and withhold the attack of his father's troops. According to the accounts, Shi Wei-a minister employed by Jin to fortify the city-refused to do it properly because he foresaw the conflict between Duke Xian and his sons (Duke Xi fifth year). Since $\mathrm{Pu}$ was not a secure fortress, it may be that Chong'er gave it up for pragmatic reasons, but the narrative insists that his decision to flee was a moral one:

\section{及難，公使寺人披伐蒲。重耳曰：君父之命不校。乃徇曰：校者，吾倠住 也。踰垣而走。披斬其祛。遂出奔翟。}

When trouble broke out, the Duke [Xian] dispatched eunuch Pi to invade Pu. Chong'er said: "The orders of the ruler and father cannot be opposed." Thereupon, he issued an announcement [for his followers]: "Those who oppose the orders are my enemies." As [Chong'er] was 
jumping over a wall, Pi cut off his sleeve. Consequently, [Chong'er] fled to the Di. (Duke Xi fifth year, 2) ${ }^{52}$

The fact that Pi managed to cut off his sleeve shows that Chong'er made a narrow escape indeed, but it also serves as a hint that his absence from Jin is not going to be permanent, promising that Chong'er has unfinished business with $\mathrm{Pi}$. Indeed, when he finally returns to Jin nineteen years later, Pi comes to see him. Chong'er refuses and confronts him, saying:

\section{夫祛猶在}

There is still that sleeve. (Duke Xi twenty-fourth year, 1$)^{53}$

However, Pi switches his allegiance and warns Chong'er of the plans to assassinate him, thus enabling the prince's successful comeback. It is thus that the little sleeve detail establishes continuity in the narrative across a nineteen-year-long gap.

The reader expects that the story will continue, but also that the unfair banishment of Chong'er will be revoked and the injustice done to him repaid. The Narrator first draws a moral portrait of the protagonist, and then finishes the account abruptly, adorning it with suggestive leftovers (the same method is applied especially in sub-story (C) that will be discussed later); the use of such devices shows us that the narrative is not so much about the "here and now," but that it is actually oriented towards the future - the reader has yet to see the unfurling of the ending he already knows.

In the meantime, though, the reader is suspended in a temporal limbo. For the ensuing nineteen years, the name of Chong'er is never mentioned in the narrative. Nevertheless, his presence is clearly perceived the entire time-as a matter of fact, it is his absence that makes it even more eminent. The reader, reading about his brother's transgressions, expects Chong'er to return at any moment. Thus, even though at this point the narrative talks about Shensheng and Yiwu, it still constitutes an integral part of Duke Wen Story-the narrative is in fact about Chong'er. Thus, sub-story (A) is a description of Shensheng's sacrifice on behalf of Chong'er; sub-story (B), on the other hand, is meant to discredit Yiwu, and thus to endorse Chong'er as Duke Wen. The reader is constantly reminded that Chong'er-Duke Wen-should be ruling in his stead. Chong'er's absence becomes evident and meaningful, performing a certain rhetorical function in the narrative.

52. Yang Bojun, Chunqiu Zuo zhuan, 305.

53. Yang Bojun, Chunqiu Zuo zhuan, 414. 
Nineteen years is a period of time long enough for Chong'er to be completely forgotten and obliterated. However, the prognostications in the narrative do not allow Chong'er to be forgotten; they prepare the ground for his comeback as a Hero. The rhetoric of suppression and silence is a narrative device justifying the nineteen-year gap in Duke Wen Story.

The delaying factor is also a way of integrating the issue of timeliness into the very structure of the narrative: the Hero must not only come at the right time; he also needs time to come-it takes time to become a Hero. From a purely dramatic point of view, the suspense surrounding his coming is crucial. In terms of the values upheld by the narrative, Chong'er's coming must not be momentary/instantaneous; the tardiness is a necessary part of it. Without the delay, the story of Duke Wen would not be complete. The contrast with Yiwu would not become evident and Chong'er would not be missed; consequently, the reader would not recognize him as a Hero, and his return would lack its fulfilling quality. In effect, it is time itself that makes Chong'er a Hero; the delay gives the reader a sense of longing and lack — an anxiety that generates the need for a fulfilling ending. It is because of the suspense that it is evident to the reader that Chong'er is Duke Wen before, after, and during-or despite-his absence. While Yiwu is compromising himself, the reader learns nothing about the deeds of Chong'er; nevertheless, it is the latter who is awaited as the one to come and save Jin.

By applying this rhetoric of silence, the Narrator passes his judgment through omission. When the chronological sequence of events does not allow him to focus on the main protagonist, who is temporarily suffering an injustice and ousted from the picture, the Narrator uses the silence created by his absence to discredit the players, who ostensibly prevail, and thus to endorse and reaffirm the absentee's moral standing. Thus, the Narrator further discloses the mechanism of timeliness. The Hero needs time to come, the promise needs time to be fulfilled, and the prediction needs time to manifest. The injustice is temporal, and the law of rewards and punishments never fails.

The predictions extrapolate the reader into the realm of the SupraNarrative: the story that is parallel, silenced, yet constantly overshadowing and ultimately superseding the one the reader is currently reading. On the surface, the Narrator is following the chronological order of events, presenting the affairs in Jin, and naturally focusing on the person of the current ruler. From the point of view of the linear Narrative, this is the "main" story-the chronicle of what "actually" happened. On this level, the Narrator appears as a historiographer recording and transmitting the events. In fact, though, he is all the time telling a story that lies beyond the "main" one, and that eventually takes over as 
"history." From that other and "higher" perspective, all the paradoxes can be readily explained. The paradoxes are necessary on the Narrative level, because similar to the predictions, they make the reader aware of the supra-reality. Without the paradox, the latter could not be perceived and understood, and, in fact, it would not exist-the Narrator needs the supra-reality in order to explain the paradoxes, and, consequently, he constructs it. Thus, the narratives on both levels are interdependent.

\section{iv. The Spirit World}

By elements in the narrative that pertain to the "spirit world," I understand occurrences and properties that could be better described "marvelous."54 Elements and phenomena of the spirit world, such as ghosts, were considered by the contemporaries as an integral part of Nature, and the Zuo zhuan narrative presents them as "historical" - events that "actually" took place. The narrative does not "create" reality; rather, it represents it.55 In effect, the "marvelous" is accepted as natural; at the same time, however, these events are marked as extraordinary: they are Heaven's direct interventions into human affairs.

The Narrator in the Zuo zhuan resorts to the spirit world in order to show that the law of justice never fails. As I argued previously, a person in possession of the quality of ming - "sagely illumination"understands and conforms to the demands of timeliness. "Sagely

54. According to Todorov's distinction between different kinds of "supernatural" in literature, when the reader, encountering a "fantastic" event in the text, "decides that new laws of nature must be entertained to account for the phenomena, we enter the genre of the marvelous"; in such a case, the reader believes that "the event has indeed taken place, [and] it is an integral part of reality-but then the reality is controlled by laws unknown to us." Otherwise, the reader may assume that the literary character "is the victim of an illusion of the senses, of a product of the imagination - and laws of the world then remain what they are"; in such a case, we are in the genre of the "uncanny." In each case, according to Todorov, the distinction depends on the reader's attitude towards the supernatural events. It is, of course, impossible to conjure the attitude of the Zuo zhuan's readers; however, the Narrator provides the reader with clear clues about how the narrative should be understood. See Tzvetan Todorov The Fantastic: A Structural Approach to a Literary Genre, trans. Richard Howard (New York: Cornell University Press, 1975).

55. Karl Kao points out that in Western literature the spirit world is "conceived mainly from the angle of creative perception (the author's projection of his vision) rather than from that of the reality represented," whereas in the Chinese context "the opposite orientation is assumed: Six Dynasties chih-kuai particularly are considered as the 'records' of facts and observable natural phenomena (or hearsay)." Even though Kao's discussion concerns literature after the Han, his observation may be applied to early historiography, on which later fiction was modeled. See Karl S. Y. Kao, Classical Chinese Tales of the Supernatural and the Fantastic (Bloomington: Indiana University Press, 1985). 
illumination" is also what enables the Actors to mete out punishments and rewards in a just manner.

In the Duke Wen Story, the virtuous Actors, Shensheng and Chong'er, suffer injustice. Shensheng is glorified as a martyr on the Supra-Narrative level, but he also gets his reward in the Narrative. He loses both the throne and life; his story, then, seems to be over-there is no "human" way for him to continue in the narrative. However, this ending is not satisfying, even though the paradox of unrewarded virtue is resolved in the Supra-Narrative. On the Narrative level, the law of justice still seems to be broken. In order to serve Shensheng justice, the Narrator resolves to the spirit world- the prince reappears in the narrative as a ghost and takes his revenge. The spirit world serves as a device to bring Shensheng back to life and to satisfy the reader's need for a just ending to the story. Chong'er, on the other hand, manages to return and claim justice within his lifetime, before his story is over. However, his comeback, too, is presented as if higher forces were at work and enabled it.

In each case, the spirit world serves as a means of presenting the Actors as "illuminated" - ming. Shensheng and Chong'er claim justice not merely for themselves. They do not come to take revenge, because their primary purpose is serving justice to others. Indeed, both Shensheng and Chong'er return as punitive ghosts—ming gui-ghosts endowed with "sagely illumination" and therefore able to discern right from wrong; the function of this special category of ghosts is to mete out punishments and rewards. ${ }^{6}$

The use of the spirit world accentuates the divine origins of ming and reveals the special relationship ming Actors have with Heaven. It reconfirms the law of punishments and rewards. Yiwu's life is spared after the battle of Han, but politically and narratologically/historiographically he is "dead" - there are no accounts on his final years on the Jin throne. Shensheng returns after his death, "spiritually" resumes the authority over Jin, and arranges for Yiwu's doom; finally, Chong'er's silenced presence overshadows the narrative, and he becomes a legend while still alive; his return resembles a resurrection—a ghost coming back to life-and a myth coming true.

\section{The Return of Shensheng}

One of Yiwu's first decisions after usurping the throne to become Duke Hui is to re-inter Shensheng's body transporting it from Quwo, where he committed suicide, back to the capital (Duke Xi tenth year, 3). Yiwu

56. I discuss this concept in much detail in Piotr Gibas, "Mozi and the Ghosts: The Concept of Ming 明 in Mozi's 'Ming gui.'” Early China 40 (2017), 89-123. 
wants to be identified with his martyred brother; therefore, he appropriates Shensheng's sacrifice in order to legitimize his own claims to the throne. In the autumn of the same year, the ghost of Shensheng appears to the officer $\mathrm{Hu} \mathrm{Tu}$ and declares:

\section{夷吾無禮, 余得請於帝矣, 將以晉界秦, 秦將祀余。}

Yiwu comports himself with no regard for the rules of propriety; I have petitioned the Lord on High and obtained his consent to grant Jin to Qin; Qin will continue the sacrifices to me. (Duke Xi tenth year, 3) ${ }^{57}$

Shensheng deems Yiwu unworthy; despite being dead, he reclaims his position of heir apparent and puts himself in charge of Jin. In that position, it becomes his right and responsibility to settle the state, and he decides to cede it to Qin. This would mean the extinction of Jin, and so $\mathrm{Hu} \mathrm{Tu}$ attempts to reason with the prince:

\section{臣聞之：「神不歆非類，民不祀非族。」君祀無乃殄乎？且民何罪？ 失刑、乏祀，君其圖之!}

I have heard: "The spirits do not absorb the fragrance of the offerings from those who are not their kin; people do not sacrifice to those who do not belong to their clan." Would, then, the sacrifices to you not be terminated? Besides, what is the crime of the people [of Jin]? You will mete out a wrong punishment and deprive yourself of sacrifices; you should better reconsider that!

(Duke Xi tenth year, 3$)^{58}$

$\mathrm{Hu}$ Tu's logic gets through. Shensheng promises to have another interview with the Lord on High and agrees to meet with $\mathrm{Hu} \mathrm{Tu}$ again in seven days. At the appointed time and place, the ghost appears through a medium- $w u$ 巫—with the following message:

帝許我罰有罪矣, 敉於韓。(Duke Xi tenth year, 3) $)^{59}$

The Lord on High has allowed me to punish only the guilty one; he shall be defeated in Han. (Duke Xi tenth year, 3$)^{60}$

Shensheng's reappearance in the narrative is yet another way of pointing at Chong'er as the legitimate ruler and to prevent the false hero from

57. Yang Bojun, Chunqiu Zuo zhuan, 334 .

58. Yang Bojun, Chunqiu Zuo zhuan, 334.

59. Yang Bojun, Chunqiu Zuo zhuan, 335.

6o. Yang Bojun, Chunqiu Zuo zhuan, 335. 
usurping the sacrifice not meant for him. The episode is clearly meant to discredit Yiwu and it is neatly woven into the network of predictions of his doom. Ostensibly, its only purpose is to disclose the new marquis's hypocrisy. Shensheng sees through Yiwu's schemes and rejects his act of piety. More importantly, though, Shensheng's return as a ghost suggests Heaven's direct involvement in solving the affairs in Jin. Shensheng has an exclusive agreement with the Lord on High, and he uses it not merely in order to take his own revenge, but, more exactly, to punish Yiwu and set the state on the right track-to finalize the coming of the "sage ruler" ming jun. In effect, both Yiwu's doom and Chong'er's comeback are brought about by divine interference. The Narrator uses the spirit world to reassure the reader about the infallibility of justice and to accentuate the "sagely illumination" of Shensheng and Chong'er.

The episode also serves as a double prediction. Apart from foretelling the time and place of Yiwu's doom, it reassures the continuity of the state of Jin and, by extension, predicts the return of Chong'er. We hear the echo of this prediction in (Duke Xi thirteenth year, 4), when the Earl of Qin is debating whether or not he should send relief grain to Jin and decides:

\section{其君是惡，其民何罪？}

Its [Jin's] ruler is indeed evil; but what is the guilt of its people? (Duke Xi thirteenth year, 4$)^{61}$

We also find it in (Duke Xi fifteenth year, 8), when the Earl of Qin justifies his decision to spare Jin by saying: "I resent its [Jin's] ruler, but I do sympathize with its people." ${ }^{62}$ In both cases, Yiwu-the current Jin ruleris alienated from his state. The correction in Shensheng's judgment is significant-he resolves to punish Yiwu alone, just as did the Earl of Qin. Noticeably, this time $\mathrm{Hu} \mathrm{Tu}$ does not contest the ghost's decision: the minister does not try to protect Yiwu-his ruler-because he agrees that he deserves to be deposed. In this case, the doom of the ruler does not imply the doom of the whole state. $\mathrm{Hu} \mathrm{Tu}$, representing the people of Jin, accepts the authority of Shensheng. The narrative begins with the words:

秋, 狐突適下國, 遇大子。

In autumn, $\mathrm{Hu} \mathrm{Tu}$ went to the lower capital [Quwo], where he encountered the eldest son [heir apparent/Shensheng]. (Duke Xi tenth year, 3$)^{63}$

61. Yang Bojun, Chunqiu Zuo zhuan, 345 .

62. 吾怨其君, 而矜其民. See n.47 above.

63. Yang Bojun, Chunqiu Zuo zhuan, 334. 
The season is specified, following the Chunqiu rules of recording events, in order to formalize it and it indicates that he is performing this at the right time; Shensheng is referred to as "heir apparent" — not a ghost, but a real person. Throughout the narrative, Hu Tu addresses him by "lord" jun 君. Thus, the ghost episode confirms Yiwu's illegitimacy-it presents him as a usurper whose fall should be to the benefit of the state; Jin's fate shall be deposited in other, more worthy hands.

The ghost of Shensheng comes to punish Yiwu for the latter's transgressions. The execution of the punishment is not instantaneous, but is put away in time-Shensheng pronounces the exact time and place of the doom. Similarly, the Earl of Qin knows that in the due time the temporary ruler of Jin will bring disaster upon himself. Thus, Yiwu is given the time to prove himself wrong: just as Chong'er needs time to come as a hero, he, too, needs time to enact his doom. Yiwu has plenty of opportunities to mend his ways, but instead he continuously takes wrong decisions. It is clear that he brings this fate upon himself by acting blindly-ignoring all the predictions, and not heeding the advice offered to him. ${ }^{64}$

The narrative about Shensheng's comeback as a ghost is meant to make up to him for the undeserved doom and, at the same time, to satisfy-on the Narrative level-the reader's sense of justice. It is presented as a "real," "historical" event, taking place in the linear time. Shensheng, wronged while alive, has his last word as a ghost. His biography is endowed with the spirit world element in order to reinforce the logic of the narrative. But also, it shows that-as an "illuminated ghost" ming gui-he is able to discern right from wrong and entitled to execute justice.

64. The prediction of this kind is a recurring narrative convention in the Zuo zhuan; by means of it, the agency of time becomes clearly visible. In the very first longer narrative in the Zuo zhuan (Duke Yin first year, 3), Duke Zhuang of Zheng 鄭莊公 refuses to destroy his brother Duan 段 and instructs the impatient adviser: "By frequently practicing unrighteousness, he will certainly bring doom upon himself; for now, just you wait and see" (多行不義, 必自獘, 子姑待之). Eventually, it is Duke Zhuang in person who metes out the punishment on Duan; however, he is merely responding to the situations provoked by his brother. Similarly, Yiwu's doom comes as a result of his own action, the intervention of Shensheng being only an illustration of this mechanism. Duke Zhuang is blamed for failing to provide a good example for his brother and thus preventing him from wrongdoing. Shensheng sets a perfect example for his brother, but the latter abuses it-he pretends to serve justice to the martyr, but in fact all he seeks is his own ill-conceived benefit. No reconciliation between the brothers is possible or expected, unlike in the case of Zhuang and Duan: Yang Bojun, Chunqiu Zuo zhuan, 7-8. 


\section{The Return of Chong'er and the Execution of Justice}

The final execution of justice comes with the return of Chong'er. Characteristically, he returns not as a human being, but a ghost. In Duke Xi twenty-third year (637 B.C.E.), Duke Hui of Jin (Yiwu) dies. His son Yu 太子囯—having just escaped from Qin, where he was kept hostage after the battle of Han-takes over as Duke Huai 晉懷公. The first command of the new ruler is that nobody must follow "the fugitive," by whom he meant Chong'er:

\section{懷公立，命無從亡人。}

Duke Huai was installed, and he ordered that no one must follow the fugitive. (Duke Xi twenty-third year, 4$)^{65}$

After nineteen years, this is the first mention of Chong'er in the text, and he is nameless - he is referred to as "fugitive." This word choice has an emphatic function: it reveals Yu's perception of Chong'er and defines his status. A "fugitive"—wang ren 亡人—is someone who has "departed," who has left the boundaries of a certain domain, state or realm. By extension, it is someone who "is no more," a dead person. This is a play on words-wang 亡 means "dead."66

Thus, through his phrasing, Yu disowns Chong'er and insists he no longer belongs in Jin. The people should not follow the one who left. In a way, he is saying: "Do not follow a specter!" The transition of power was clearly not smooth, and the rush in which $\mathrm{Yu}$ issues the command indicates that the opposition against him and the support for Chong'er were considerable. Chong'er's reappearance is sudden, improbable, and unreal, as if he were returning from the dead.

Shensheng's return as a ghost is "historicized." It is presented in the narrative as a "real" — "historical" — event, as something that really happened. He is presented as alive, even though he is dead. In contrast, Chong'er returns as a "wang ren," and thus bears the characteristics of a dead person.

The episode of Shensheng's return fits perfectly into the logic of the Narrative. The reader expects that the last word concerning Shensheng had not yet been said and that the injustice done to him ought to be revenged. The Narrative satisfies the reader's expectation and presents

65. Yang Bojun, Chunqiu Zuo zhuan, 402.

66. The Grand Historiographer tai shi 大史 of Jin accused Zhao Dun of murder, because "fleeing the state, he did not cross the borders" (亡不越竟); leaving the domain is necessary to be considered "exiled." Wang Li renders "亡" simply as "not there/ absent" (不在). 
the wronged person himself serving the right. In other words, the reader knows that sooner or later Shensheng has to appear again in the Narrative, and the fact that he comes as a ghost does not diminish the effect of the event.

Likewise, the reader is prepared for the comeback of Chong'er, and therefore knows immediately who the nameless "fugitive" is. As I argued before, Chong'er never really left the Narrative and the Narrator keeps the reader constantly aware of him through predictions and comparisons; moreover, because the marvelous is presented as history, it is natural that, in reverse, historical events also contain elements from the spirit world.

\section{v. Sub-Story $(\mathrm{C})$ - Chong'er as a Hero and an Illuminated Ruler}

Sub-stories (A) and (B) discussed above narrate the events in Jin during Chong'er's absence. They explain the fates of Shensheng and Yiwu and project them on the fate of Chong'er, thus constituting an integral part of the Duke Wen Story. Sub-story (C) is an account of Chong'er's life in exile, and it completes the narrative of Chong'er becoming Duke Wen of Jin.

Sub-story $(\mathrm{C})$ is a compact narrative directly preceding the accounts of the exiled prince's return to Jin. The text begins with a short review of the reasons of his exile, serving as a reminder to the reader about who Chong'er was. It recalls his filial behavior and indicates that his expulsion from Jin was unjust. ${ }^{6} 7$

The following is a narrative of Chong'er's odyssey, written in retrospect. It not only fills the nineteen-year-long information gap, but it also prepares the stage for the grand finale: Duke Wen's rule in Jin that brings the state, and indeed the entire Zhou domain, back into order. Each episode carries a portent that is played out later in the final part of Duke Jin's story; thus, the narrative shows that his comeback is predestined and desired. The story is equipped with elements from the spirit world to indicate that the event of Chong'er's return as Duke Wen was, in effect, brought about by divine powers. As such, the feeling of restored order not only resolves suspense, but it also reveals the outcome as having been inevitable. This notion of inevitability is what completes the restoration of order.

The Actor's relationship with time-in narrative terms-becomes very clear: Chong'er is acting out the time of his absence. The account of his wanderings through the states shows how Chong'er is making connections and gaining experience and support that he is going to use

67. The expulsion is referred to in the text as nan 難 (misfortune): Yang Bojun, Chunqiu Zuo zhuan, 404 . 
later as the hegemon. His absence from Jin-both physical and on the Narrative level—was necessary for him to become a hero.

The portents that dot the narrative further enforce this point: they need time to come true. The account of Chong'er's adventures may be written in retrospect, but in fact it is a predicted future-it establishes the ground and foretells Duke Wen's actions after his return to Jin.

In his study on heroic tradition in China, C. H. Wang introduces the concept of "cultural heroism" and points out that in China "the display of martial power ( $w u$ 武) is never as worthy as the exhibition of cultural eloquence (wen 文)." As Wang observes, "Chinese ethics in general almost repudiates martial spirit from heroism"; furthermore, according to Wang, the contrast between wen and wu "sets up the rhetorical pattern" in the so-called Weniad - the great national "epic" of the Zhou people, glorifying the Zhou conquest of Shang in 1111 B.C.E. ${ }^{68}$ However, as Wang emphasizes, "in the sanctification of King Wu of Chou's military action against the Shang, Confucianism judges the conquest incomplete until the weapon is put away and the rite performed appropriately." In fact, Wang argues, "the figure is King Wu's father, King Wen, whose position in the sequence is so significant as a pivot that the epic, as it were, is the Weniad." King Wen took over China in the twelfth century B.C.E. purely by means of his virtue; therefore, Wang concludes, "in the Weniad, in which the cultivation of wen, or cultural elegance, is emphasized, the martial-heroic spirit is kept muted." ${ }^{69}$ In effect, according to Wang's definition, in Chinese tradition a "hero" is a king who is a sage and who uses culture and virtue for his governance over the people, instead of arms.

The Duke Wen Story draws a clear parallel between King Wen of Zhou and Duke Wen of Jin. As I pointed out before, Gongsun Zhi of Qin articulates it in juxtaposition with Yiwu; also, King Wen and Duke Wen's bearing the same reign name, and that name being "wen" 文, speaks for itself. Chong'er, as a Zuo zhuan character, is modeled after King Wenhe is a "cultural" hero. He repudiates arms: he first refuses to fight his father, and all the wars he wages as Duke Wen are punitive expeditions; and he establishes his rule in Jin and his hegemony over the entire Zhou domain by means of virtue and ritual. Sub-story $(\mathrm{C})$ is an "epic" depicting Chong'er's formation as a hero and it forwards him not as a wu, but a ming and a wen ruler.70

68. According to Wang, the Zhou conquest is "the most glorious military campaign most widely and profoundly documented in Chinese history": C. H. Wang, "Towards Defining a Chinese Heroism," Journal of the American Oriental Society 95.1 (1975), 27.

69. Wang, "Towards Defining a Chinese Heroism," 27.

70. It is very likely that sub-story $(\mathrm{C})$ is a rendition of the parallel oral tradition-a pre-existing myth of Duke Wen, Illuminated Ruler and Hero, and the related worship.

footnote continued on next page 
In Duke Xi twenty-third year (637 в.C.E.) the "sage ruler myth" comes true: Chong'er returns to Jin to bring back justice and order. The narrative of Duke Wen's years on the throne depicts his way to hegemony and presents him as a ming jun-illuminated ruler. As I pointed out in my earlier study on this concept, ming - the ability to justly mete out punishments and rewards-as an indispensable quality in a sage ruler. ${ }^{71}$ The Zuo zhuan Narrator emphasizes three characteristic aspects of Duke Wen's rule that put him in line with the sage kings-sheng wang 聖王一of Antiquity and prove his "sagely illumination" ming: (1) rewarding the virtuous, appointing the capable, and punishing the evil; (2) knowing, relying on, and transforming the people; and (3) being truthful一xin 信. $7^{2}$

Yiwu is presented in the Narrative as an illegitimate ruler who usurped the throne from Chong'er ignored predictions. Yu was deemed unworthy not only because he was Yiwu's son, but more importantly because of the quality of his ming. On the eve of Chong'er's return to Jin, diviner Bu Yan 下偃 predicts Yu will have "no posterity in Jin" qi he hou zhi you 其何後之有, because he is unable to apply correct punishments, and thus has “no ming" bu ming 不明 (Duke Xi twenty-third year, 4). ${ }^{73}$ Yan's judgment is truly devastating: no ming means no future.

In effect, Chong'er's return has a salving quality-it is presented as a rescue of Jin from the hands of illegitimate and incompetent rulers. He begins his rule from punishing the traitors and rewarding all of the faithful followers, thus correcting the mistakes made by his predecessors; 74 and his government has a strong transformative impact on the people. 75 He restores King Xiang in the Zhou capital in Duke Xi twenty-fifth year

Storytelling constituted part of the hero cult and ritual. So did history writing-the account of Chong'er's "odyssey" is a performance-through-narration. The story is the narrative of that ritual, the "literary" expression of it, and its being archetypal is nothing else but the refection of its ritualistic origin. It shows that things must always happen in a certain way; as such, the events are predictable. The story is known in advance, and it serves as an endorsement for the Hero; it serves as a commemoration, but also shapes the ideas about other heroes-to-come. They need to be the same, just as Chong'er shares the same traits with King Wen of Zhou.

71. Gibas, "Mozi and the Ghosts."

72. As I demonstrate, xin is a necessary component of ming. In the Zuo zhuan narrative, the Superior Man junzi declares that the covenant between the King of Zhou and Duke Wen is xin "truthful," thus recognizing the "sagely illumination" of Duke Wen. Gibas, see n.67 above.

73. Yang Bojun, Chunqiu Zuo zhuan, 403.

74. Yang Bojun, Chunqiu Zuo zhuan, 412-19.

75. "Upon entering the state, the marquis of Jin [Duke Wen] first educated the people... Only when the people were able to receive the orders without mistake, then 
(635 B.C.E.). In Duke Xi twenty-eighth year (632 B.C.E.), he fights the battle with $\mathrm{Chu}$, which confirms his hegemony over the states. Before the battle, even the king of Chu recognizes Duke Wen's sagehood and superiority, and he understands that acting against him is futile:

\section{無從晉師！晉侯在外十九年矣，而果得晉國。險阻艱難，備嘗之矣；民 之情76偽，盡知之矣。天假之年 $77 ，$ 而除其害 $78 ，$ 天之所置，其可廢乎？}

Do not pursue the Jin army! The Marquis of Jin was away [from the state] for nineteen years, and in the end he has succeeded in getting possession of Jin. He experienced all kinds of dangers, obstacles, difficulties, and hardships; he knows thoroughly the truthfulness and falsehood of people. Heaven granted him many years and removed from his way those who wanted to kill him; can someone installed by Heaven be disposed of? (Duke Xi twenty-eighth year, 3$)^{79}$

Thus, the Chu ruler characterizes Duke Wen as a man who knows the people and for whom their feelings are transparent; he is appointed by Heaven, and he has a special connection with time. He has enough of it, and he is not too early or too late. Heaven endows Duke Wen with time, so he does not need to worry about it. Therefore, nothing can stand in his way. The prolonged period of absence becomes a sign of Duke Wen's special connection with Heaven and a proof of his sagehood-he is outside the time (and outside the chronological Narrative).

After the battle of Chengpu 城幞, where the Chu troops were defeated, Duke Wen and the army of Jin returned triumphantly to the capital. There, the Duke distributed lavish rewards and meted out punishments. The Superior Man junzi 君子 commented: ${ }^{80}$

文公其能刑矣, 三罪 ${ }^{81}$ 而民服。詩云「惠此中國, 以四方」, 不失賞、 刑之謂也。

he used them" (晉候始入而教其民， ... 民聽不惑, 而後用之) (Duke Xi 27th year, 4): Yang Bojun, Chunqiu Zuo zhuan, 447.

76. Yang Bojun reads 情 as 實: Yang Bojun, Chunqiu Zuo zhuan, 456.

77. According to Yang Bojun, this refers to the nineteen years in exile-a long time that was granted by Heaven to Chong'er so that he was able to return: Yang Bojun, Chunqiu Zuo zhuan, 456.

78. According to Yang Bojun, this is a reference to Duke Huai (Yu) and his follower Lü 呂 who were planning to assassinate Chong'er upon his return: Yang Bojun, Chunqiu Zuo zhuan, 456.

79. Yang Bojun, Chunqiu Zuo zhuan, 456.

8o. In the context of the Zuo zhuan, the "superior man" 君子 is conventionally agreed to be Confucius.

81. Reference to three people guilty of treason during the battle. 
Duke Wen indeed does know how to mete out punishments, because he [executed] three criminals, and the people followed him. As the Odes say, "By applying virtue to the central state, one [applies it to] the four quarters," which depicts not failing in applying correct rewards and punishments. (Duke Xi twenty-eighth year, 6) ${ }^{82}$

Thus, Duke Wen owes the hegemony to his "sagely illumination," which, in turn, is the engine of his transformative power. By correctly executing justice, he educates the people and brings order to not only Jin, but also the rest of the Zhou realm.

Duke Wen brings order gradually, by means of virtue, and through observing proper ceremonies. ${ }^{8} 3$ He transforms the Zhou realm and his achievements are long lasting. He is the object, the medium, and the actor of ming. He overcomes the past, transforms the present, and establishes an orderly future. Duke Wen goes down in history as a great hero, one of the five hegemons $b a$, a virtuous and illuminated ruler ming jun, and is compared to the sage kings of antiquity. His story shows that justice is served in a timely manner.

After presenting the three Actors in the Duke Wen story, let me turn to their advisers - the Prognosticators. They are the ones in the narrative who directly construct the moral portrait of the Actors-their ming or the lack thereof-for the reader.

\section{The Prognosticators-Omen Reading}

Like the Actors, the Prognosticators are also "historical figures," but they are not playing an "active" role in the narrative-the story is not about them. Instead, they witness the events and they read them as omens portending the future. They are the avatars of the Narrator in the Narrative. The Prognosticators possess "sagely illumination," that is, because they know the past, they are able to predict the future. They identify the ming Actors, and they communicate with the spirit world, behaving as the go-betweens of the human and the divine. They expose the "illuminated" Actors-Heroes, and by doing that-as well as by foretelling the future-they reveal their own ming.

A good example of this rule is the figure of Shi Wei, who is the first in the Duke Wen story who predicts trouble in Jin. In his analysis of Shensheng's plight, he uses the Tai Bo parallel as an antidote: Shi Wei-a Prognosticator- "works" for the Narrator by helping to explain the

82. Yang Bojun, Chunqiu Zuo zhuan, 472.

83. As assessed by the junzi, "In this military campaign, Jin was able to attack by means of virtue" (晉於是設也, 能以德攻) (Duke Xi 28th year, 3). Yang Bojun, Chunqiu Zuo zhuan, 467 . 
injustice. He predicts not only Shensheng's deposal—which he could have deduced from political calculation-but also the rise of Chong'er. In other words, Shi Wei adds meaning to Shensheng's fall, making it look like a self-sacrifice and reads it as an omen. Bringing up Tai Bo, the Prognosticator demonstrates that he already knows the future to come, and by reading the archetype, he is able to determine future events. According to him, the casus of Shensheng is just the same as the historical precedence and it will bring the same results. Shi Wei's prediction is based on his personal wisdom and ability to analyze the situation. There are no straightforwardly divine elements in it, such as resorting to oracles or to spiritual forces; instead, there is a strong sense of reality, and the intrinsic knowledge of "how things work." However, the determinative tone of the prediction makes it resemble a prognostication: ${ }^{84}$

大子不得立矣。

The eldest son will not be installed [on the throne]. (Duke Min first year, 6$)^{85}$

The minister is not issuing a warning or making a guess; he already knows what actually will happen in the future, and he is foretelling it. The rest of Shi Wei's statement includes: the explanation, based on the reading of the signs; the calamity, due to the abuse of the rules of timeliness; the judgment-Shensheng is not guilty and able to save his good name; and the advice/solution-submit to Heaven's will and follow the examples from the past.

Shi Wei is clearly reading an omen. It is noteworthy that this oracle in not delivered to a superior. The minister is not addressing anyone, but instead merely "thinking aloud" to himself. His only addressee is the reader; in effect, Shi Wei replaces the Narrator, or, more exactly, serves as the Narrator's mouthpiece-avatar. In this way, the Prognosticator gains the Supra-Narrative perspective and is able to narrate the events far into the future on the chronological level.

The structure and context of Shi Wei's prognostication render the narrative a formulaic character, which suggests that it comes from some "higher," perhaps even spiritual source or inspiration. It is not a coincidence that Shi Wei entrusts Shensheng's fate to Heaven. It is

84. By "prediction," I understand foretelling of the future based on a guess or a feeling, whereas a "prognostication" is based on an actual act divination, that is, reading and interpreting omens and signs; the latter is more formalized and carries a stronger persuasive power; it renders the narrative more determinative and, consequently, more convincing.

85. Yang Bojun, Chunqiu Zuo zhuan, 258. 
by observing the way of Heaven that Shi Wei is able to understand the mechanism of meting out justice based on timeliness, the causes and consequences of events, and, consequently, to foretell the future. Thus, Shi Wei is performing an act of moral and situational divination over Shensheng and Jin's future. He derives his knowledge from Heaven and uses it to discern the right and the wrong. Shi Wei is ming. He reveals his own sagehood by reading the omens and recognizing the "sagely illumination" of the Actors.

\section{Timeliness and the Writers of History}

As I suggested at the beginning of this study, the system of timeliness in historiography echoes the naïve, mantic concept of time that can be observed in daybooks, and, in effect, "canonical" historiographical works, such as Chunqiu and the Zuo zhuan, emerge as quasi-daybooksmanuals for understanding the mechanism of timeliness.

Michael Loewe in his study on rishu suggests the existence of a relationship between daybooks and contemporary historical writings. As he points out, the tabular form used to list the prescriptions in rishu resembles that found in the Shi ji; moreover, he observes that other types of documents, such as historical writings, feature the same subjects as the almanacs: religious activities, human destinies, behavior, and projects. This is the list of matters for which advice was sought in both daybooks and documents that, as Loewe puts it, "may or may not derive from mantic considerations." According to him, these other documents "form the context in which the almanacs should be considered." 86 As I argue in this study, it is the concept of time that connects both groups of texts.

As shown by Mu-chou Poo, the function of a daybook or an almanac is to advise whether a given day is auspicious or inauspicious for a certain kind of activity and for a particular kind of person. ${ }^{87}$ The prognostications in daybooks are based on a fixed system in which "time" figures as an agent: it is in itself "good" or "bad," and it determines the course of events on a given day. Every undertaking is either timely or untimely, and the daybook advances the information regarding that. The idea of the cosmos emerging from daybooks is purely mechanistic: certain things always happen on certain days due to the correlative configurations beyond human control; every such phenomenon is already

86. Michael Loewe, "The Almanacs (Jih-shu) from Shui-hu-ti: A Preliminary Survey," in Divination, Mythology and Monarchy in Han China (Cambridge: Cambridge University Press, 1994), 226.

87. Mu-chou Poo, In Search of Personal Welfare: A View of Ancient Chinese Religion (Albany: State University of New York Press, 1998). 
fixed according to its correspondence with the nature of the days, but since it is a known fact, a person can follow the instructions prescribed in the daybook to maneuver her way around it.

As we could see in the examples from the Zuo zhuan narrative, understanding the mechanistic nature of time and organizing it into a system of timeliness makes the future-or time itself-predictable, and thus controllable. In other words, people are able to control time by understanding its nature; they can use the mechanism of timeliness in order to predict things - the daybook helps them determine whether an action is timely or not. Thus, daybooks are tools for manipulating time-fatethey enable one to avoid bad fortune and ensure that the events turn the favorable way; also, they foster a worldview in which good and bad fortune - and, by extension, future - can be prognosticated.

The yue ling almanacs are based on the same calendrical precepts as rishu and likewise build on the idea that time is predetermined as either good or bad; in comparison, however, they represent a more elaborate worldview and serve a different function. Unlike rishu, the yue ling are not a practical manual that anyone can consult at will (e.g. when in need to travel somewhere), but, true to their name, they are "ordinances" ling 令-they determine what one must do in each month of the year in order to avoid calamities. Rishu provide general advice that could be applied by individual users; the yue ling, on the other hand, are addressed to the population at large and to the rulers of states in particular, and they leave a clear message that the calendar absolutely needs to be observed and the ordinances implemented, lest the course of nature be disturbed and calamity should strike. For example, if ordinances for summer are implemented in spring, then "winds and rains will not be seasonable, grasses and trees will wither early, and the state will thereupon become alarmed." 88 Thus, the text warns that ignoring or disobeying the injunctions will result in a natural disaster affecting everybody.

Donald Harper deems the yue ling "political" in nature and concludes that "astrological and calendrical data ... . are set forth as the foundation of an orderly state." 89 Indeed, the philosophical treatises that follow the initial hemerological chapter of each book of the almanacs establish a direct link between the prognostications and running a state.

According to the worldview presented in these treatises, an effective government of a state depends entirely on the ruler's observance of the

88. 孟春行夏令, 則風雨不時, 草木早槁, 國乃有恐: John Knoblock and Jeffrey Riegel, The Annals of Lü Buwei (Stanford: Stanford University Press, 2000), 63-4.

89. Donald Harper, "Warring States Natural Philosophy and Occult Thought," in The Cambridge History of Ancient China (Cambridge: Cambridge University Press, 1999), $831-32$. 
calendar; at the same time, the ruler, in order to fulfill his role as the Son of Heaven, must coordinate his actions with the cycle of Heaven, i.e. following the instructions provided by the yue ling; as Harper puts it, "the king translated Heaven's harmonious operation into social reality"; ;o furthermore, Knoblock and Riegel observe that according to the yue ling, a ruler's destruction is not something outside of his control and he should not merely study the signs sent from Heaven, as diviners do, but adjust his course of action accordingly. ${ }^{91}$

In other words, the state depends on the actions of the ruler, and the ruler can only be a sage if he observes the instructions sent by Heaven and spelled out in the yue ling; an enlightened (sage) ruler can foresee and prevent any calamity, thus his failure or success are his own doing.

If we consider the yue ling treatises in this way, we will see that they constitute a plan for a perfect government; they serve as moral guidelines for the ruler and draw the picture of a true sage, with the list of the attributes and qualities that he needs to possess and cultivate; thus, according to the yue ling, the sage must be impartial, correctly assess and judge people (properly apply punishments and rewards, appoint the worthy and expel the unworthy), engage only in just wars, honor teachers and elders, understand music, perform self-scrutiny and practice moderation, and be sincere. Special emphasis is put on the sage's "farsightedness" chang jian 長見, which implies the ability to foresee the future:

\section{故審知今則可知古, 知古則可知後, 古今前後一也。故聖人上知千歲, 下知千歲也。}

Thus, one who knows the present well can know the past, and one who knows the past can know later ages. Past and present, before and after, have one and the same principle. Thus, the sage knows the millennium that preceded and the thousand years that will follow. $9^{2}$

As we should note from the above passage, the sage is able to foresee the future only because he knows the "principle" underlying the mechanism of time-he understands how time works: the sage can foresee the future, because he studies the past; knowing the past and the future enables him to properly assess the present and thus apply correct measures to his government. In order to avoid future misfortunes, the sage must be aware of the past precedence. As explained in "Observing Signs" 觀表, a chapter of Lüshi chunqiu, also devoted to prognostication

90. Harper, “Warring States," 832.

91. Knoblock and Riegel, The Annals of Lü Buwei, 60.

92. Knoblock and Riegel, The Annals of Lü Buwei, 253. 
but not part of the "Almanacs," this is the very quality that distinguishes the sage from others:

\section{聖人之所以過人以先知, 先知必審徵表, 無徵表而欲先知, 堯、舜與眾 人同等 ... 眾人則無道至焉。無道至則以為神, 以為幸。非神非幸, 其數不得不然。}

A sage surpasses ordinary men because he uses foreknowledge. Foreknowledge invariably involves attentiveness to confirming characteristics and visible indicators. Without them, even Yao and Shun would be ordinary men ... Ordinary people lack the Dao to achieve foreknowledge, and since they do, they attribute it to magic or to luck; but it is not a matter of either magic or of luck. The techniques of the sages must be as they have been described. 93

As we saw in Duke Wen Story, the prescience is the defining quality of the sage. According to the Lüshi chunqiu 呂氏春秋, the ruler is farsighted when he observes the calendar and follows the prognostications ("visible indicators" or "signs" zheng biao 徵表). However, the Zuo zhuan presents a much more complex relationship between the sage and time: the sage not only prognosticates and follows the signs; also, the power to foresee the future is not a goal in itself-this ability alone is not what makes him a true sage; rather, the emphasis is on actual acting according to the rules of timeliness - the true sage always does the right thing at the right moment. In order to accomplish that, the sage must know the right time. The sage's prescience, then, is not exactly the ability to foretell what will happen in the future, but when to act in order to make the future favorable.

Daybooks are written pronouncements of prognosticators rizhe 日者, who knew and understood the nature of time, and therefore were able to foretell the future. ${ }^{4}$ In the rish $u$ worldview, time determines people's lives profoundly, forcing them to follow the calendar and adjust their activities to its course; on the other hand, however, time's regularity and predictability puts people in control and leaves a lot of room for manipulation. This vision of time is "fatalistic" only in the sense that a person cannot "make" a day good or lucky; it is possible, however, to plan the future by picking a lucky day and suitably matching activities to the proper day. The relationship between humans and the cosmos is not

93. Knoblock and Riegel, The Annals of Lü Buwei, 540-41.

94. Li Ling introduces the term rizhe as a denomination for the authors of the almanacs and describes daybooks as their "statements/parlances" (日者之說); almanacs were the expressions of the expertise of the rizhe, the products of their work, and, to a certain degree, the means by which the prognosticators circulated their ideas: Li Ling, Jianbo gushu, 177-78. 
entirely mutual, but the mechanistic nature of time renders it predictable and thus conquerable. The rishu, as a transcription of the course of time-and, thus, the universe-is a tool for manipulating "time-fate": one's fate depends on the timeliness of one's action. An Actor can choose to act in a timely or untimely manner (examples of Shensheng and Yiwu) and one can also manipulate fate (Duke Xian, who deliberately changes Shensheng's fate by means of timeliness). In this way, "time" and "fate" become interdependent. As daybooks promise, correct application of the mechanism of timeliness ensures success and good fortune.

The rizhe, through their daybooks, provided people with solutions in everyday life. They studied the working of the universe, and they revealed and explained the unknown and the mysterious. Li Ling draws a straight line connecting the rizhe with the "historiographers" shi; in his opinion, both groups of officers belong to the same tradition stemming from the court “calendar specialists"—riguan 日官 or riyu 日御. As Li Ling points out, the daybook prognosticators and the historiographers later on split ways: starting from the Warring States period, the parlance of the rizhe was circulating among common people and was no longer affiliated with the court. In other words, the almanacs acquired the status of popular and not official literature. ${ }^{95}$ Nonetheless, the historiographers derived their ideas about the working of time from the same source as the authors of almanacs, and they write history applying the system of prediction based on timeliness. The rizhe did not compose almanacs for didactic purposes; they did not convert the concept of time into an ideology meant to control people by influencing their behavior, as is the case in contemporary historical works. The function of rishu—and the rizhe's knowledge of time-is practical.

In the Zuo zhuan, Duke Xian of Jin (Shensheng, Yiwu, and Chong'er's father) can be seen applying this mechanistic concept of time. By deliberately sending Shensheng on untimely assignments, he disqualifies his son as heir-apparent and blocks his way to the throne. Duke Xian understands how time works in daybooks' terms-it is either good or bad, and one needs to act accordingly to assure success. Can we then say that Duke Xian is ming, because he understands the mechanism of timeliness? As implied in the Zuo zhuan narrative, his knowledge of time is superficial, his judgment shortsighted, and the success he achieves by his actions short-lived. Duke Xian manipulates time, but he has no minghe does not see what future his act of manipulation will bring. Quite the contrary, he misreads the future and things turn out completely opposite to what he has planned. Duke Xian may believe he has conquered time, but instead, time conquers him. In the end, in the "narratological" future,

95. Li Ling, Jianbo gushu, 178 . 
it is Shensheng and Chong'er who will succeed; they really "conquer" time, in that their "sagely illumination" enables them to choose timely actions. Duke Xian loses because he acts in the absence of ming.

\section{Conclusions}

The Zuo zhuan Narrator's main focus is ming jun-the illuminated ruler. His purpose is to answer the question of how is the illuminated rulerand the time of his "coming" - to be known? Thus, the Narrator takes upon himself the task of "illuminating" - ming — the reader by revealing to him the way of knowing the future. He achieves this by explaining to the reader the workings of time. Timeliness-shi-is what defines and legitimizes him. The coming of the illuminated ruler can be known in advance, and he is the right one if he comes at the right time. The Narrator analyses what lead to Chong'er's becoming Duke Wen and shows how it was known all along from the very beginning. Chong'er was always Duke Wen, Hero-Illuminated Ruler, and his coming was only a matter of time. Therefore, the Narrator tells the "history"-Chong'er's past-as a prognosticated future, and all the events are presented as predictions of what follows next. The Narrator demonstrates that one can know the future from knowing the past: by studying and correctly understanding - ming - history. The future is written in the past, and the past is written in the future.

Confucius reveals his own sagehood by identifying the lin and understanding its untimely coming as a portent and a sign of the lack of a ming wang. Through his historiographical performance, the Zuo zhuan Narrator, too, identifies the Illuminated Ruler; by means of applying the moral code based on timeliness, he evaluates the Actors, explains the present, and foresees the future. In effect, the Narrator proves his own ming. He sees and exposes the right and wrong, and, like a punitive "illuminated" ghost ming gui, he metes out punishments and rewards. History writing perceived from this perspective gains a moral and political significance, and it sanctions the sagely role of the historiographer. Knowing and understanding history is tantamount to being a sage.

The temporal structure of the Zuo zhuan episodes is not just an abstract organizational principle, but the very canvas on which the story is written; it carries with it a particular moral system - "timely" and "untimely" action correspond with morally charged concepts of "right" and "wrong." In other words, a person can only be considered "virtuous" if his actions are executed at the right time. Therefore, and this is key, the ability to see if the time is right — the quality of "sagely illumination" ming —is the most important of all qualities. An "untimely" action, no matter how well intentioned, cannot be successful; a truly virtuous person understands 
that, and therefore waits for the suitable moment to act. In effect, then, "time" or "timeliness" — shi-emerges as the prime agent that determines the course of history. It imposes limits on the Actors, who need to adjust their actions accordingly. Consequently, shi influences a person's fate; but, from the all-important perspective of History, what matters is the moral choice and wisdom of the Actors as they try to "see" whether they should act or not. A ming person understands the workings of time and knows that acting against it is both futile and immoral.

The Actor's fate depends entirely on the moral choices he makes; these have to be ming - be based on the recognition of the right timing. It is by being ming or not that the Actor positions himself in history. The story lives after the speaker dies-both Shensheng and Chong'er are aware of their own historicity. They consciously negotiate and create their historical profiles to represent them in the future. Shensheng dies actually and Chong'er figuratively for the sake of winning life in the memory of the posterity. Yiwu, on the other hand, unaware of being a historical figure, acts against time and is wiped off the historical record. The rhetorical transformation of a human into a non-human corresponds with the supra-narratological metamorphosis of an individual into a historical figure immortalized through a historical record.

The study of individual biographies from this perspective reveals how the Zuo zhuan establishes the relationship between people and time. An untimely - bu shi-and thus improper action disturbs the course of Nature and leads to complications and anomalies. Humans are tied to Nature in that all their activities are regulated by the calendar, whose operation is ritualistic. It is because of this that all transgressions result in grave consequences. In other words, an inappropriate action will be avenged not necessarily by those who were directly affected by it, but by the larger force lying behind the main principle-Time. The narrative is not a warning, but it reflects this principle, and it does serve as moral guidance. According to the tradition, Confucius compiled the Annals in order to "condemn the wicked and praise the virtuous"; therefore, he exposed their bare acts, without commentary, in a written historical record. The commentators viewed Chunqiu as history speaking for itself. In the Zuo zhuan, through the portraits of the Actors, the Narrator conveys the message that their "position in history" - the "history's" judgment-is not accidental. This is especially visible in cases of injustice, when virtue seems to go unrewarded and wickedness unpunished. It is then that the Narrator's questioning comes into play and when he discloses the moral law of rewards and punishments based on the understanding of-and obeisance to-timeliness.

The Zuo zhuan does not explicitly pronounce the law by which punishments and rewards are based on timeliness; but it can be considered an 
illustration and even a "product" of it. The concept of ming- "sagely illumination"-is the key to implementing this law and, at the same time, exposing it. In ming inheres the ability to mete out punishments and rewards in a just manner, and its standard derives from an accurate understanding of "timeliness" shi. Illumination is, at the same time, both the servant of justice and the means by which justice is served. Its exercise implies discerning the distinction between right and wrong, and knowing the time when justice is to be executed. The Narrator metes out punishments and rewards by evaluating the Actors in retrospect and assigning them a place in history-he is able to correctly read the past; the Prognosticators do the same by always pronouncing the right judgment and predicting the fates of the Actorsthey are able to see the future; the Actors practice their ming —or the lack thereof-in the narrative's "here and now" by making moral choices between right and wrong; the Hero is a ming Actor, and a ming jun-illuminated ruler-is the ruler who quite literally punishes the wicked, rewards the virtuous, and whose government depends on good advice.

Historiography in China originated as a religious practice. The written record of events had apotropaic functions and was meant for a future use. The office of shi combined the duties of ritual masters, prognosticators-astrologers and diviners-and historiographers, hence the transmission of ideas. The historiographers were not just recording the events, but communicating with the spirits; they were preserving and studying the past in order to prognosticate about the future. Studying history, in this worldview, was the same as consulting the sagesancestors through oracle bones or other forms of divination.

以歷史為未來：關於《左傳》中的時、預測與歷史敘述

\title{
齊百思 \\ 提要
}

\begin{abstract}
本文論證《左傳》中的歷史敘事建立在「時」與「不時」的概念上。 敘事裡人物行動的結果是否成功取決於「時」（則吉）或「不時」（則 凶）。此概念源自同時期日書與月令等傳統。中國早期歷史記述者試圖 憑藉過去預測未來。從這一角度來看, 了解歷史意味著掌握驅動歷史事 件的因素。以史為鑒對於「預知」未來起著至關重要的作用。
\end{abstract}

Keywords: Zuo zhuan, history, historiography, historical narrative, prediction, prognostication, time, timeliness

《左傳》, 歷史, 歷史敘述, 時, 預言, 預測 